\title{
Research Article \\ Effect of Nitrite Ions on Steel Corrosion Induced by Chloride or Sulfate Ions
}

\author{
Zhonglu Cao, Makoto Hibino, and Hiroki Goda \\ Concrete Laboratory, Department of Civil Engineering, Kyushu Institute of Technology, Kitakyushu-shi 804-8550, Japan
}

Correspondence should be addressed to Zhonglu Cao; caozhonglu@126.com

Received 24 June 2013; Revised 29 September 2013; Accepted 4 October 2013

Academic Editor: W. Ke

Copyright (C) 2013 Zhonglu Cao et al. This is an open access article distributed under the Creative Commons Attribution License, which permits unrestricted use, distribution, and reproduction in any medium, provided the original work is properly cited.

The influence of nitrite concentration on the corrosion of steel immersed in three simulated $\mathrm{pH}$ environments containing chloride ions or sulfate ions has been investigated by comparing and analyzing the change of half-cell potential, the change of threshold level of $\mathrm{Cl}^{-}$or $\mathrm{SO}_{4}{ }^{2-}$, the change of threshold level of $\mathrm{NO}_{2}{ }^{-} / \mathrm{Cl}^{-}$or $\mathrm{NO}_{2}{ }^{-} / \mathrm{SO}_{4}{ }^{2-}$ mole ratio, and the changes of anodic/cathodic polarization curves and Stern-Geary constant $B$. The corrosivity of chloride ions against sulfate ions also has been discussed in $\mathrm{pH}$ 12.6, $\mathrm{pH} 10.3$, and $\mathrm{pH} 8.1$ environments containing $0,0.053$, and $0.2 \mathrm{~mol} / \mathrm{L} \mathrm{NO}_{2}$, respectively.

\section{Introduction}

The corrosion of reinforcing steel in concrete has become one of the most severe deterioration mechanisms in concrete structures. It is generally accepted that due to the high alkalinity of cement hydration products, a protective layer of iron oxides is formed on the surface of steel, which provides adequate corrosion resistance. However, with the penetration of chloride, sulfate, and carbon dioxide and the appearance of concrete cracking, this protective layer becomes unstable and corrosion initials.

As one of the methods is to prevent steel corrosion, nitrite-based corrosion inhibitors, irrespective of being directly added into concrete during the mixing process or penetrating into concrete by the surface-applied remedial treatment, have been widely investigated in chloride-contaminated concrete [1-3], carbonated concrete [4-6], and cracked concrete $[7,8]$, and their inhibiting efficiencies also have been checked in simulated concrete pore solution, such as in highly alkaline solution [9-12], carbonated solution [12-14], and neutral and acid solution $[12,15]$. Most of these results confirm the effectiveness of nitrite in increasing the chloride threshold level, delaying the onset of corrosion, and reducing the corrosion rate once the corrosion was initiated, but there is no general consensus on the $\mathrm{NO}_{2}{ }^{-} / \mathrm{Cl}^{-}$mole ratio above that the preservation of the passive state can be ensured; suggested values for this threshold range from 0.11 to 1.0 in concrete and from 0.07 to greater than 2 in simulated pore solution. This difference in the threshold level of $\mathrm{NO}_{2}^{-} / \mathrm{Cl}^{-}$ mole ratio obtained from various literatures might be due to the way of determining the concentrations of chloride and nitrite in concrete (free ions and total ions, etc.), the different qualities of mortar and concrete used in the experiments, the different components of simulated pore solution, and the different surface topographies and compositions of the steel. Comparing and analyzing these literatures, the authors find the contents of available nitrite are different in these studies. So whether it is possible that the nitrite concentration has an influence on this threshold value attracts the interest of us, and up to now, no published literature gives the answer. Another problem here is that the inhibiting efficiency of nitrite in carbonated concrete with or without chloride is not ideal, so whether the high $\mathrm{pH}$ environment plays a role in assisting nitrite to inhibit chloride-induced corrosion, as far as known by the authors, no literature clarifies this.

As described above, many researches have been done for chloride-induced steel corrosion. However, fewer works are focused on sulfate-induced steel corrosion, even the corrosion mechanism of sulfate ions is still not clear, and there are also some controversies on the corrosivity of sulfate against chloride ions in alkaline and neutral environments [16-23]. Additionally, all of these works for sulfate-induced 
corrosion are just performed in concrete or solution without the addition of any corrosion inhibitor. Little attention has been given to the effect of nitrite ions on sulfate-induced corrosion, and furthermore, reports on the corrosivity of sulfate against chloride, under the action of nitrite, are extremely scarce.

Besides these, the effect of nitrite ions on the polarization behaviors of steel also has attracted the interest of the authors. As it is known that the corrosion current density of steel is usually calculated by the use of the Stern-Geary equation defined as $i_{\text {corr }}=B / R p$, where $R p$ is the polarization resistance and $B$ is a constant which varies with the expression that $B=\beta_{a} \beta_{c} /\left(2.3\left(\beta_{a}+\beta_{c}\right)\right)$, where $\beta_{a}$ and $\beta_{c}$ are the anodic and cathodic Tafel slopes obtained from the anodic and cathodic polarization curves of steel, respectively. Generally, the calculation of $i_{\text {corr }}$ mainly focuses on the determination of $R p$ and rarely gives an attention to the value of $B$. The value of $B$ is commonly considered to be $26 \mathrm{mV}$ for steel in corroded state and $52 \mathrm{mV}$ for steel in passive state [24]. As we know, the polarization behavior of steel is affected by many factors, such as oxygen and corrosion inhibitors, so the direct use of these $B$ values is suitable or not, is worthy of discussing. What is more, with the increasing application of corrosion inhibitors, some concern should be given to the effect of corrosion inhibitors on $B$ value. Nitrite that performs as an anodic inhibitor can repair the passive film and improve the polarization resistance $R p$; however, whether it has an effect on Stern-Geary constant $B$ should be checked and clarified, because in most cases, especially for onsite measurement of corrosion rate, the value of $B$ is taken for granted without any experimental verification, so the calculation of corrosion current density might be misled if any influence of nitrite on the Tafel slope exists.

For all these reasons, the main objective of this paper was to investigate and clarify the influence of nitrite concentration and $\mathrm{pH}$ environments on the inhibiting efficiency of nitrite and the influence of nitrite on the anodic/cathodic polarization curves of steel and Stern-Geary constant $B$. Additionally, the corrosivity of chloride and sulfate on steel was also compared. Because the corrosion of steel in concrete is difficult to be investigated, and so all experiments in this study were carried out in simulated chemical environments.

\section{Experimental}

Cold-rolled carbon steel sheets (JIS G3141 SPCC-SB) with a dimension of $60 \times 60 \times 1 \mathrm{~mm}$ were selected to use in this study. The composition of the steel sheet was (wt $\%$ ): $0.1025 \%$ C, $0.5204 \% \mathrm{Mn}, 0.0193 \% \mathrm{P}, 0.0097 \% \mathrm{~S}$, and balance Fe. At one corner, lead wire was fixed to the steel by screw and the connection area was sealed by epoxy resin. The exposed area of the steel was $67.7 \mathrm{~cm}^{2}$. Before the experiments, steel sheets were polished by sandpaper and cleaned with acetone.

The corrosion of steel sheets was investigated in three different $\mathrm{pH}$ environments $(\mathrm{pH}$ 12.6, $\mathrm{pH}$ 10.3, and distilled water) simulating the highly alkaline environment, weakly alkaline environment, and neutral environment that really existed on the surface of steel in concrete. The $\mathrm{pH} 12.6$ and $\mathrm{pH}$

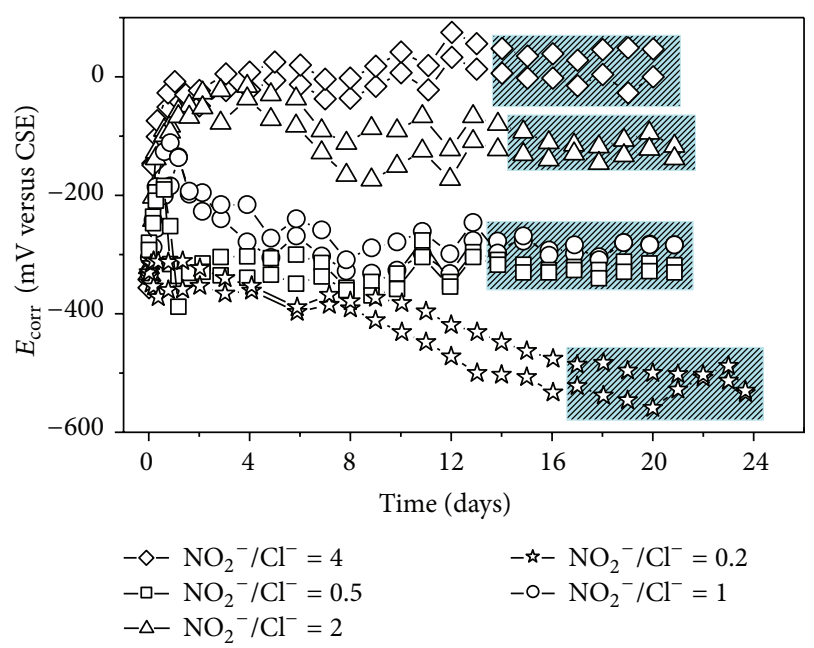

FIGURE 1: Time evolution curves of $E_{\text {corr }}$ in distilled water containing $0.2 \mathrm{~mol} / \mathrm{L} \mathrm{NO}_{2}{ }^{-}$and with different mole ratio of $\mathrm{NO}_{2}{ }^{-} / \mathrm{Cl}^{-}$.

10.3 environments were made by mixing different contents of $\mathrm{LiOH}$ and $\mathrm{H}_{3} \mathrm{BO}_{3}$. $\mathrm{LiOH}$ and $\mathrm{H}_{3} \mathrm{BO}_{3}$ were chosen for the following reasons. Firstly, they worked as buffer solution which could make the $\mathrm{pH}$ in a constant level during the whole experiment process, and secondly $\mathrm{LiOH}$ was often used as electrolyte for electrochemical removal of chloride from concrete structures, and thirdly $\mathrm{Li}^{+}$that is mainly in the form of $\mathrm{LiNO}_{2}$ was usually added into concrete to prevent the concrete expansion caused by alkali-silica reaction. The use of $\mathrm{LiOH}$ and $\mathrm{H}_{3} \mathrm{BO}_{3}$ could not reflect the real concrete pore solution that is composed of $\mathrm{Na}^{+}, \mathrm{K}^{+}, \mathrm{Ca}^{2+}, \mathrm{OH}^{-}, \mathrm{CO}_{3}{ }^{2-}$, $\mathrm{HCO}_{3}{ }^{-}$, and so forth, but it still can simulate the possible $\mathrm{pH}$ environments that exist in concrete. Although the pore solution compositions (cation type and anion type) had an effect on the protective properties of the passive oxide films and the corrosion behavior of steel [6, 13, 25-27], the focus of this work was to investigate the influence of $\mathrm{pH}$ environments and nitrite ions on steel corrosion induced by chloride or sulfate, not to study the effect of other cation/anion ions. Therefore, the use of $\mathrm{LiOH}$ and $\mathrm{H}_{3} \mathrm{BO}_{3}$ might be not the best, but it was suitable in this work.

For each $\mathrm{pH}$ environment, sodium nitrite was added with the concentration of $0,0.02,0.053,0.2,0.53 \mathrm{~mol} / \mathrm{L}$, respectively, while sodium chloride or sodium sulfate was added according to the mole ratio of $\mathrm{NO}_{2}{ }^{-} / \mathrm{Cl}^{-}$or $\mathrm{NO}_{2}{ }^{-} / \mathrm{SO}_{4}{ }^{2-}$ given in Table 1 or Table 2, respectively. With the presence of nitrite, the $\mathrm{pH}$ of distilled water increased to about 8.1.

For each combination of $\mathrm{NO}_{2}{ }^{-}$and $\mathrm{Cl}^{-}$or each combination of $\mathrm{NO}_{2}{ }^{-}$and $\mathrm{SO}_{4}{ }^{2-}$ in three different $\mathrm{pH}$ environments as given in Table 1 or Table 2, two specimens were performed at the same time, and half-cell potential referred to as $\mathrm{Cu} / \mathrm{CuSO}_{4}$ Electrode (CSE) was measured at set intervals until the potential reached a constant value. The time taken for the stable of potential was more than 10 days as shown in Figure 1. The final half-cell potential of steel, in each given combination, was calculated by averaging the potential value of two specimens, where the value of each specimen was 
TABLE 1: Experimental design for chloride-induced corrosion.

\begin{tabular}{|c|c|c|c|c|c|c|c|c|c|}
\hline \multirow{2}{*}{$\mathrm{pH}$} & \multirow{2}{*}{$\frac{\mathrm{NO}_{2}{ }^{-} \mathrm{mol} / \mathrm{L}}{0}$} & \multicolumn{8}{|c|}{$\mathrm{Cl}^{-} \mathrm{mol} / \mathrm{L}$} \\
\hline & & - & - & 0.4 & 0.2 & $0.1^{*}$ & 0.05 & - & $0^{*}$ \\
\hline \multirow{4}{*}{ pH $12.6 \pm 0.3$} & 0.02 & - & $0.1^{*}$ & - & - & - & - & - & - \\
\hline & 0.053 & 0.53 & 0.265 & 0.106 & 0.053 & 0.027 & - & - & 0 \\
\hline & 0.2 & - & 1 & 0.4 & 0.2 & $0.1^{*}$ & 0.05 & - & $0^{*}$ \\
\hline & 0.53 & - & - & 1.06 & 0.53 & 0.265 & 0.133 & 0.066 & 0 \\
\hline \multirow{5}{*}{$\mathrm{pH} 10.3 \pm 0.3$} & 0 & - & - & 0.4 & 0.2 & $0.1^{*}$ & 0.05 & - & $0^{*}$ \\
\hline & 0.02 & - & $0.1^{*}$ & - & - & - & - & - & $0^{*}$ \\
\hline & 0.053 & 0.53 & 0.265 & 0.106 & 0.053 & 0.027 & - & - & 0 \\
\hline & 0.2 & - & 1 & 0.4 & 0.2 & $0.1^{*}$ & 0.05 & - & $0^{*}$ \\
\hline & 0.53 & - & - & 1.06 & 0.53 & 0.265 & 0.133 & 0.066 & 0 \\
\hline \multirow{5}{*}{ Distilled water } & 0 & - & - & 0.4 & 0.2 & $0.1^{*}$ & 0.05 & - & $0^{*}$ \\
\hline & 0.02 & - & $0.1^{*}$ & - & - & - & - & - & $0^{*}$ \\
\hline & 0.053 & 0.53 & 0.265 & 0.106 & 0.053 & 0.027 & - & - & 0 \\
\hline & 0.2 & - & 1 & 0.4 & 0.2 & $0.1^{*}$ & 0.05 & - & $0^{*}$ \\
\hline & 0.53 & - & - & 1.06 & 0.53 & 0.265 & 0.133 & 0.066 & 0 \\
\hline Mole ratio & $\mathrm{O}_{2}{ }^{-} / \mathrm{Cl}^{-}$ & 0.1 & 0.2 & 0.5 & 1 & 2 & 4 & 8 & - \\
\hline
\end{tabular}

TABle 2: Experimental design for sulfate-induced corrosion.

\begin{tabular}{|c|c|c|c|c|c|c|c|c|}
\hline \multirow[t]{2}{*}{$\mathrm{pH}$} & \multirow{2}{*}{$\frac{\mathrm{NO}_{2}{ }^{-} \mathrm{mol} / \mathrm{L}}{0}$} & \multicolumn{7}{|c|}{$\mathrm{SO}_{4}^{2-} \mathrm{mol} / \mathrm{L}$} \\
\hline & & - & - & - & 0.2 & $0.1^{*}$ & 0.05 & 0.025 \\
\hline \multirow{3}{*}{$\mathrm{pH} 12.6 \pm 0.3$} & 0.02 & 0.2 & $0.1^{*}$ & 0.04 & 0.02 & 0.01 & - & - \\
\hline & 0.053 & - & 0.265 & 0.106 & 0.053 & 0.027 & 0.013 & - \\
\hline & 0.2 & - & - & 0.4 & 0.2 & $0.1^{*}$ & 0.05 & 0.025 \\
\hline \multirow{4}{*}{$\mathrm{pH} 10.3 \pm 0.3$} & 0 & - & - & - & 0.2 & $0.1^{*}$ & 0.05 & 0.025 \\
\hline & 0.02 & 0.2 & $0.1^{*}$ & 0.04 & 0.02 & 0.01 & - & - \\
\hline & 0.053 & - & 0.265 & 0.106 & 0.053 & 0.027 & 0.013 & - \\
\hline & 0.2 & - & - & 0.4 & 0.2 & $0.1^{*}$ & 0.05 & 0.025 \\
\hline \multirow{4}{*}{ Distilled water } & 0 & - & - & - & 0.2 & $0.1^{*}$ & 0.05 & 0.025 \\
\hline & 0.02 & 0.2 & $0.1^{*}$ & 0.04 & 0.02 & 0.01 & - & - \\
\hline & 0.053 & - & 0.265 & 0.106 & 0.053 & 0.027 & 0.013 & - \\
\hline & 0.2 & - & - & 0.4 & 0.2 & $0.1^{*}$ & 0.05 & 0.025 \\
\hline \multicolumn{2}{|c|}{ Mole ratio of $\mathrm{NO}_{2}{ }^{-} / \mathrm{SO}_{4}{ }^{2-}$} & 0.1 & 0.2 & 0.5 & 1 & 2 & 4 & 8 \\
\hline
\end{tabular}

determined by averaging the data obtained in the stable part of potential versus time curve (as shaded part shown in Figure 1). During the whole experimental process, the $\mathrm{pH}$ value and temperature of solution were monitored all the time to make sure that they still maintained a constant level, and the time taken for the visible formation of rust was also recorded. At the end of the experiments, specimens were taken out from the solutions and examined the formation of any visual rust on their surface. Whether the corrosion occurred or not for each combination was judged according to Table 3.

Anodic and cathodic polarization curves of steel were only carried out in the combinations marked as "*" in Tables 1 and 2. The reference electrode used here was $\mathrm{Ag} / \mathrm{AgCl}$ electrode and the counter electrode was platinum. Prior to the polarization measurement, the steel had been immersed in the solution more than 15 days and the $E_{\text {corr }}$ had reached a stable value. The cathodic polarization was done firstly, which started from $E_{\text {corr }}$ toward the negative direction with the interval of $-25 \mathrm{mV}$ (at the changing rate of $1 \mathrm{mV} / \mathrm{s}$ ). After the potential was set, 30 seconds were necessary to wait before writing down the current value. After finishing cathodic polarization, the steel was continued to be immersed in the solution about one day for the recovery of $E_{\text {corr }}$. And after that, the anodic polarization was started from $E_{\text {corr }}$ toward the positive direction with the interval of $25 \mathrm{mV}$ (at the speed of $1 \mathrm{mV} / \mathrm{s}$ ). After setting the potential, 30 seconds are necessary to wait before writing down the current value. Generally, a potential scan greater than $\pm(50$ to 100$) \mathrm{mV}$ about $E_{\text {corr }}$ is required to reach the potential at which the anode Tafel or cathode Tafel behavior dominates and linear polarization is expected [28]. Tafel slopes $\beta_{a}$ and $\beta_{c}$ in this study were calculated by using the data that obtained between $E_{\text {corr }} \pm 75$ and $E_{\text {corr }} \pm 300$. 
TABLe 3: Corrosion judgment defined in this study.

\begin{tabular}{lccc}
\hline Case & Specimen 1 & Specimen 2 & Judgments \\
\hline 1 & Corrosion & Corrosion & Corrosion \\
2 & Corrosion & No corrosion & Uncertain \\
3 & No corrosion & Corrosion & Uncertain \\
\hline
\end{tabular}

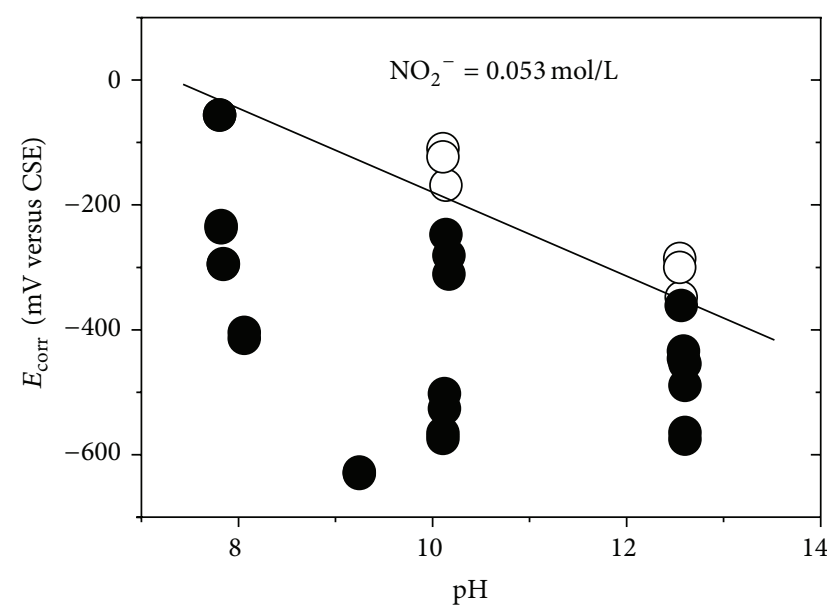

(a)

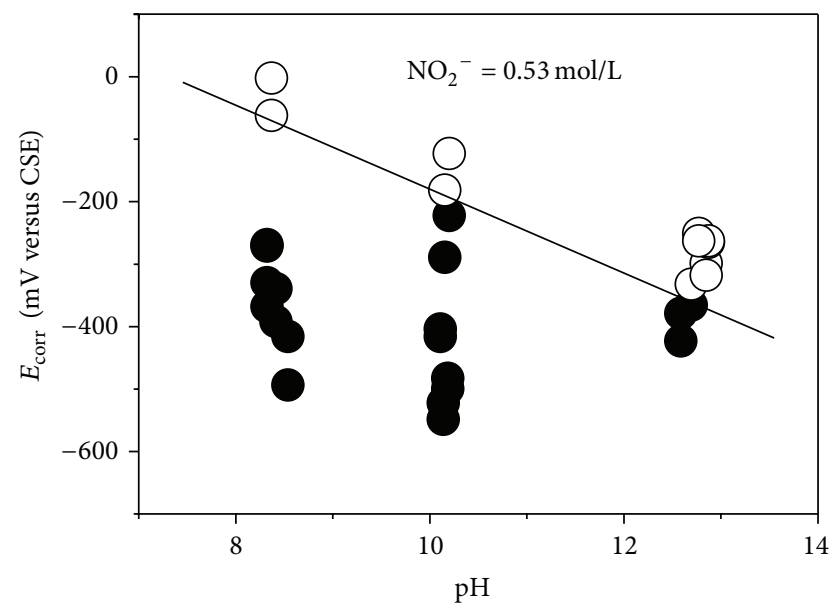

Corrosion

No corrosion

(c)

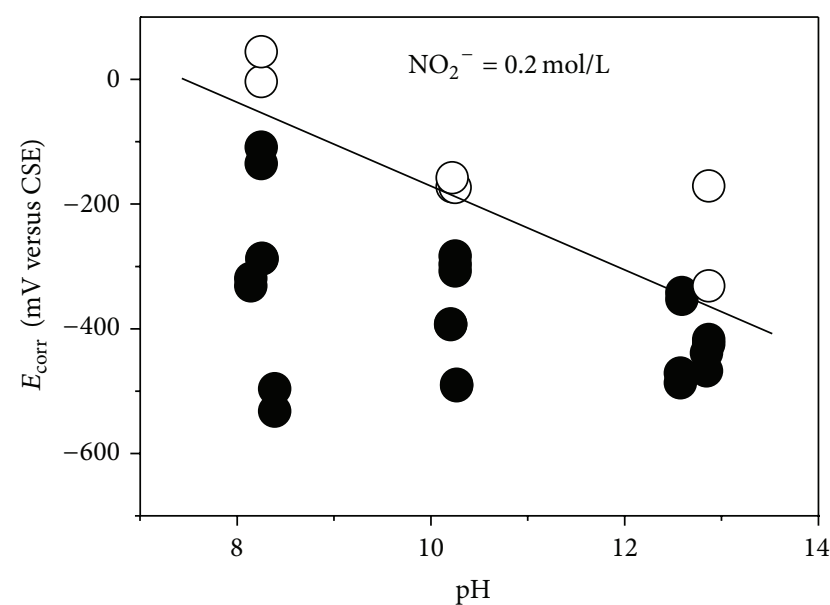

(b)

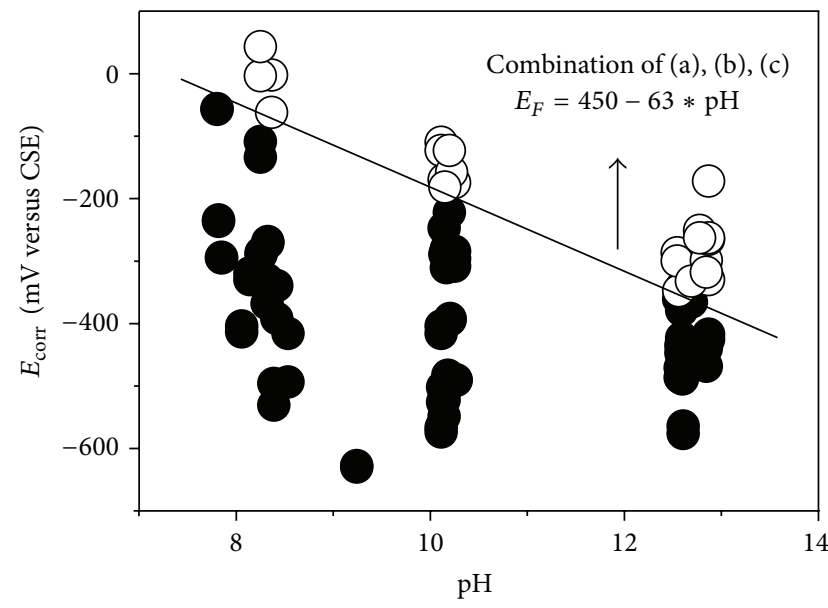

Corrosion

No corrosion

(d)

FIGURE 2: Relationship between $E_{F}$ and $\mathrm{pH}$ for chloride-induced corrosion. (a) $\mathrm{NO}_{2}{ }^{-}=0.053 \mathrm{~mol} / \mathrm{L},(\mathrm{b}) \mathrm{NO}_{2}{ }^{-}=0.2 \mathrm{~mol} / \mathrm{L},(\mathrm{c}) \mathrm{NO}_{2}{ }^{-}=$ $0.53 \mathrm{~mol} / \mathrm{L}$, and (d) combination of (a), (b), and (c).

\section{Results and Discussion}

According to the experimental results, the $E_{\text {corr }}$ of steel immersed in different $\mathrm{pH}$ environments with the absence and presence of $\mathrm{NO}_{2}{ }^{-} / \mathrm{Cl}^{-}$or $\mathrm{NO}_{2}{ }^{-} / \mathrm{SO}_{4}{ }^{2-}$, as given in Tables 1 and 2, was shown in Figures 2 and 3. The $E_{\text {corr }}$ presented here was calculated by averaging the data obtained in the stable part of potential versus time curve. The surface state of steel was marked as filled circle for corrosion and empty circle for no corrosion. From the figure, it can be found that there was a pretty clear dividing line between passive state and corrosion state. The potential that changes abruptly from passive state to corrosion state is called Flade potential $\left(E_{F}\right)$, which is the lowest potential of film formation and has a good linear relationship with $\mathrm{pH}$ values as reported by other literatures $[29,30]$. Usually, the lower the $E_{F}$ is, the stronger the passivation ability of steel is, and the passive film becomes more stable.

The possible influence of $\mathrm{NO}_{2}{ }^{-}$concentration on the relationships between $E_{F}$ and $\mathrm{pH}$ for chloride-induced corrosion 


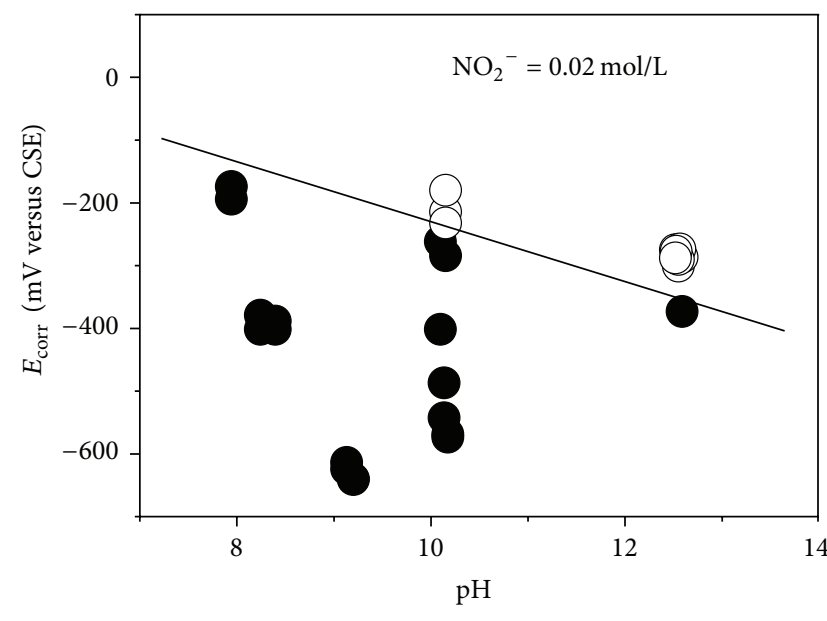

(a)

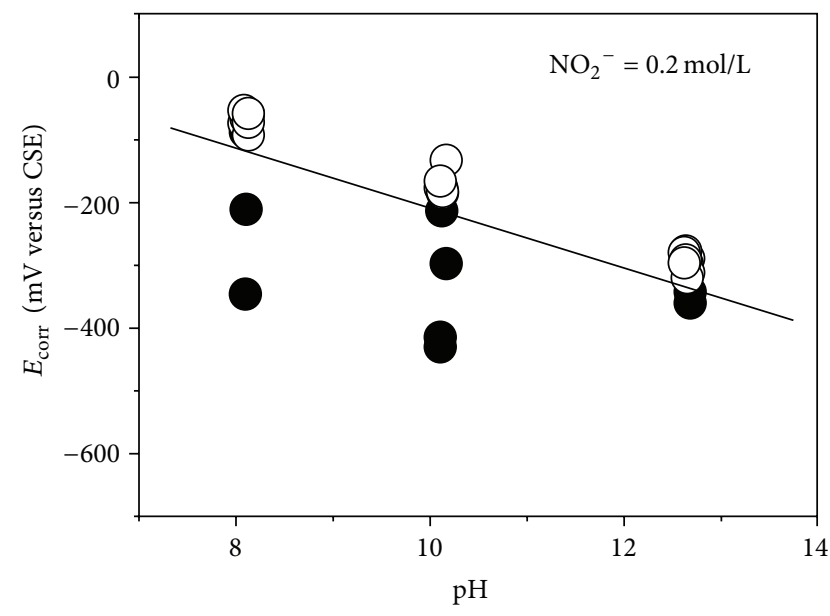

Corrosion

No corrosion

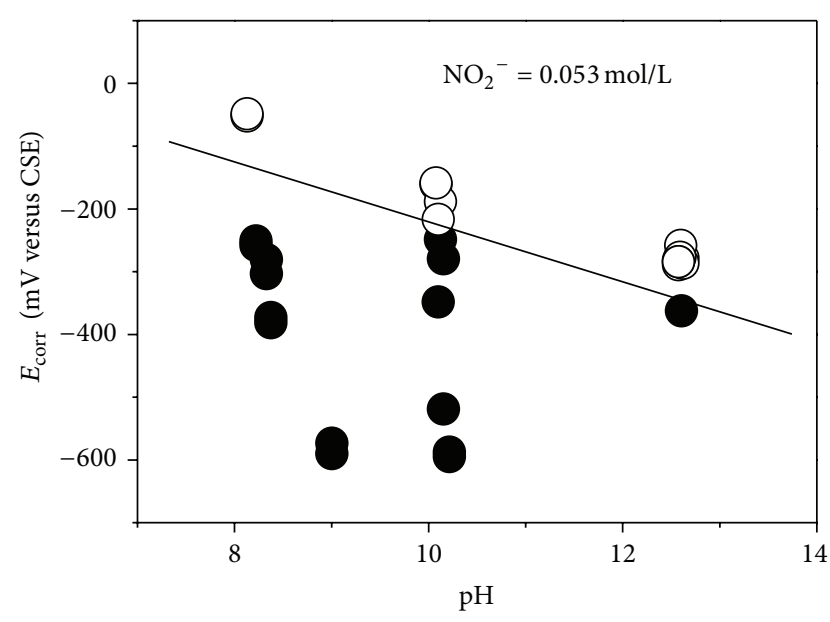

(b)

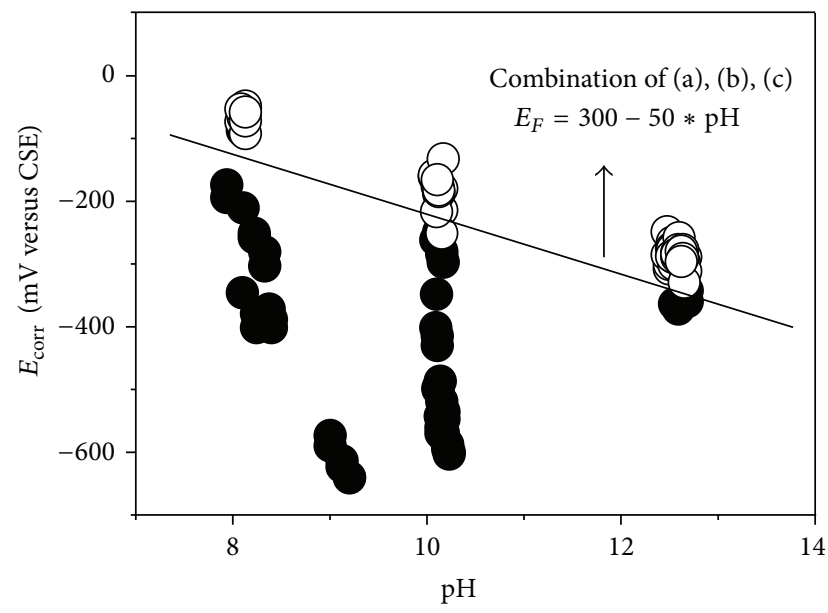

Corrosion

No corrosion

(c)

(d)

FIGURE 3: Relationship between $E_{F}$ and $\mathrm{pH}$ for sulfate-induced corrosion. (a) $\mathrm{NO}_{2}{ }^{-}=0.02 \mathrm{~mol} / \mathrm{L}$, (b) $\mathrm{NO}_{2}{ }^{-}=0.053 \mathrm{~mol} / \mathrm{L},(\mathrm{c}) \mathrm{NO}_{2}{ }^{-}=$ $0.2 \mathrm{~mol} / \mathrm{L}$, and (d) combination of (a), (b), and (c).

and sulfate-induced corrosion also had been investigated. From Figures 2 and 3, it can be found that the $\mathrm{NO}_{2}{ }^{-}$concentration that changed from $0.053 \mathrm{~mol} / \mathrm{L}$ to $0.53 \mathrm{~mol} / \mathrm{L}$ for chloride-induced corrosion or from $0.02 \mathrm{~mol} / \mathrm{L}$ to $0.2 \mathrm{~mol} / \mathrm{L}$ for sulfate-induced corrosion had little influence on the linear relationship between $E_{F}$ and $\mathrm{pH}$, which also means that the use of the relationship between $E_{F}$ and $\mathrm{pH}$ as the criterion for corrosion judgment is reasonable in this work. So, in this study, based on the experimental results, the relationships between $E_{F}$ and $\mathrm{pH}$ were given out in the form of $E_{F}=$ $450-63 * \mathrm{pH}$ for chloride-induced corrosion as shown in Figure 2(d) and $E_{F}=300-50 * \mathrm{pH}$ for sulfate-induced corrosion as given in Figure 3(d), which were used as the corrosion criterion for the following result analysis.

3.1. $E_{\text {corr }}$ Induced by $\mathrm{Cl}^{-}$. Figure 4 describes the effect of nitrite concentration on $E_{\text {corr }}$ induced by chloride in three $\mathrm{pH}$ environments. The $E_{\text {corr }}$ of steel obviously increased with the presence of nitrite for all $\mathrm{pH}$ environments, especially for low $\mathrm{pH}$ environment. The increment of potential in $\mathrm{pH} 8.1$ was greater than that in $\mathrm{pH}$ 12.6. So with the decreasing of $\mathrm{pH}$, nitrite became more effective to increase the $E_{\text {corr }}$, but it was not helpful to inhibit the corrosion. This was because the $E_{F}$ was $-344 \mathrm{mV}$ for $\mathrm{pH} 12.6,-199 \mathrm{mV}$ for $\mathrm{pH} 10.3$, and $-60 \mathrm{mV}$ for $\mathrm{pH}$ 8.1, increased with the decreasing of $\mathrm{pH}$. If the $E_{\text {corr }}$ was greater than $E_{F}$, the steel would be passivated; otherwise, the steel was corroded.

Nitrite concentration and $\mathrm{pH}$ had an influence on the increment of $E_{\text {corr }}$. In $\mathrm{pH} 12.6$ environment, for the given chloride content, the $E_{\text {corr }}$ of steel increased with the increasing of nitrite concentration, and this increment was more evident when chloride content was higher. However, in $\mathrm{pH}$ 10.3 and $\mathrm{pH} 8.1$ environments, when nitrite was increased from 0.2 to $0.53 \mathrm{~mol} / \mathrm{L}$, the increment of steel potential was not obvious. The $E_{\text {corr }}$ with $0.53 \mathrm{~mol} / \mathrm{L}$ nitrite was equal to or even lower than that with $0.2 \mathrm{~mol} / \mathrm{L}$ nitrite. No benefit 


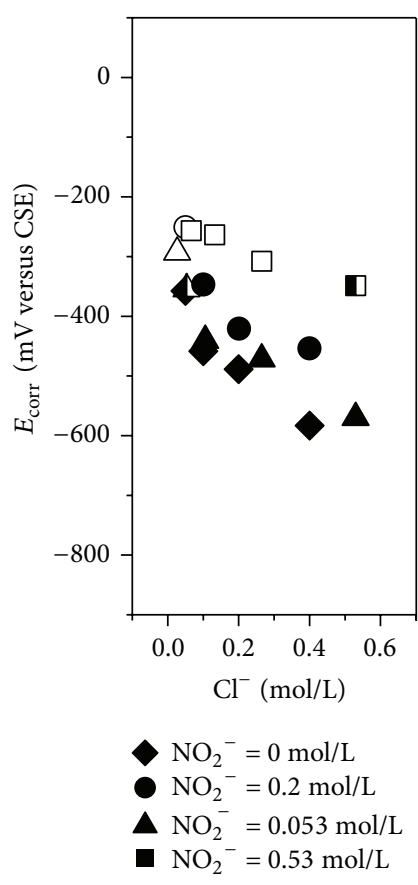

(a)

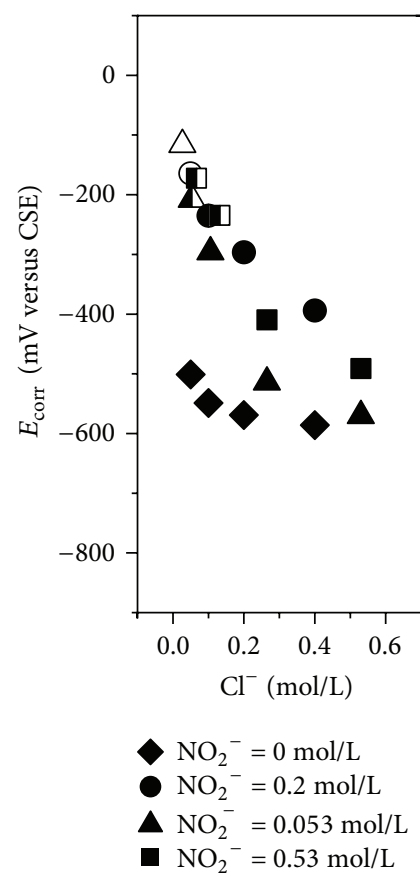

(b)

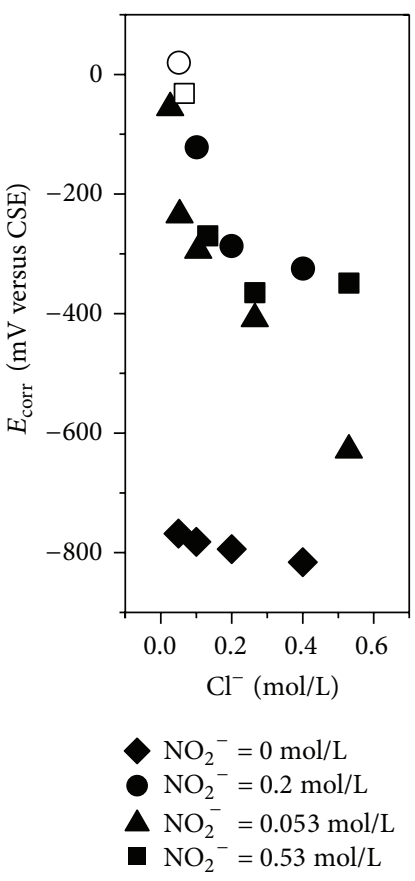

(c)

FIgURE 4: Effect of $\mathrm{NO}_{2}{ }^{-}$and $\mathrm{pH}$ on $E_{\text {corr }}$ induced by $\mathrm{Cl}^{-}$. (a) $\mathrm{pH}=12.6$, (b) $\mathrm{pH}=10.3$, and (c) $\mathrm{pH}=8.1$.

on the further increase of $E_{\text {corr }}$ can be obtained from higher nitrite concentration in $\mathrm{pH} 10.3$ and $\mathrm{pH} 8.1$ environments, and this indicates that the ability of nitrite to improve steel potential was limited and weakened.

3.2. $E_{\text {corr }}$ Induced by $\mathrm{SO}_{4}{ }^{2-}$. Figure 5 presents the effect of nitrite on $E_{\text {corr }}$ induced by sulfate in three $\mathrm{pH}$ environments. In $\mathrm{pH}$ 12.6, irrespective of the presence or absence of nitrite, $E_{\text {corr }}$ did not change significantly with the increasing of sulfate, even no rust can be found on the surface of steel after 23 days. The increment of $E_{\text {corr }}$ was negligible after the presence of nitrite. In $\mathrm{pH} 10.3, E_{\text {corr }}$ decreased with the increasing of sulfate concentration. Rust can be found on the surface of steel, but most of the area was still in good state. In $\mathrm{pH}$ 8.1, with the absence of nitrite, the entire steel surface was corroded severely. $E_{\text {corr }}$ increased with the presence of nitrite, but low concentration of nitrite $(0.02 \mathrm{~mol} / \mathrm{L})$ resulted in the formation of corrosion pitting on the surface of steel. The concentrations of nitrite had an influence on steel potential. For highly alkaline environment with $\mathrm{pH} 12.6$, with the increasing of nitrite concentration, the increment of potential was not obvious, even the decrease of potential can be found according to the experimental results. However, for the conditions of $\mathrm{pH} 10.3$ and $\mathrm{pH}$ 8.1, with the raising of nitrite concentration, the potential increased significantly, and this increment was more evident when sulfate content was high.

3.3. Relationship between $\mathrm{E}_{\text {corr }}$ and $\mathrm{NO}_{2}{ }^{-} / \mathrm{Cl}$. $\mathrm{E}_{\text {corr }}$ had a good linear relationship with $\log \left(\mathrm{NO}_{2}{ }^{-} / \mathrm{Cl}^{-}\right)$and increased with the increasing of $\mathrm{NO}_{2}{ }^{-} / \mathrm{Cl}^{-}$mole ratio, as shown in
Figure 6. In $\mathrm{pH} 12.6$ environment, the concentration of nitrite almost had no influence on the curve of $E_{\text {corr }}$ versus $\log \left(\mathrm{NO}_{2}{ }^{-} / \mathrm{Cl}^{-}\right)$, but in $\mathrm{pH} 10.3$ and $\mathrm{pH} 8.1$ environments, with the increasing of nitrite concentration, the curve shifted toward the direction of higher $\mathrm{NO}_{2}{ }^{-} / \mathrm{Cl}^{-}$mole ratio, which resulted in the decrease of $E_{\text {corr }}$ for the same $\mathrm{NO}_{2}{ }^{-} / \mathrm{Cl}^{-}$. This means that the inhibiting ability of nitrite to per unit of chloride was weakened in $\mathrm{pH} 10.3$ and $\mathrm{pH} 8.1$ environments compared to that in $\mathrm{pH} 12.6$ environment.

For the specified nitrite concentration at constant $\mathrm{pH}$, the changing of $\mathrm{NO}_{2}{ }^{-} / \mathrm{Cl}^{-}$mole ratio not only affected the $E_{\text {corr }}$, but also influenced the initial time of corrosion. For example, in distilled water with $0.2 \mathrm{~mol} / \mathrm{L}$ nitrite (as shown in Figure 1), when the mole ratio of $\mathrm{NO}_{2}{ }^{-} / \mathrm{Cl}^{-}$was changed with $4,2,1,0.5$, and 0.2 , the stable self-potential was changed correspondingly with $20,-121,-288,-325$, and $-514 \mathrm{mV}$, and the initial time of corrosion was also changed correspondingly with $>20,5.8,1.6,0.8$, and 0.1 days. Both $E_{\text {corr }}$ and the corrosion initial time increased with the increasing of $\mathrm{NO}_{2}{ }^{-} / \mathrm{Cl}^{-}$, which can also be confirmed in other conditions shown in Table 1. All this indicates that the value of $\mathrm{NO}_{2}{ }^{-} / \mathrm{Cl}^{-}$ had great influence on steel corrosion. The higher value of $\mathrm{NO}_{2}{ }^{-} / \mathrm{Cl}^{-}$makes the steel passivate, while the lower value of $\mathrm{NO}_{2}{ }^{-} / \mathrm{Cl}^{-}$makes the steel corrode. So the use of $\mathrm{NO}_{2}{ }^{-} / \mathrm{Cl}^{-}$ mole ratio as parameter to evaluate the inhibiting efficiency of nitrite on chloride-induced corrosion is feasible, and there must be a threshold level of $\mathrm{NO}_{2}{ }^{-} / \mathrm{Cl}^{-}$which can determine whether the steel is corroded or not. In this study, the threshold levels of $\mathrm{NO}_{2}{ }^{-} / \mathrm{Cl}^{-}$can be calculated based on the $E_{F}$ and the good linear relationship between $E_{\text {corr }}$ and $\log \left(\mathrm{NO}_{2}{ }^{-} / \mathrm{Cl}^{-}\right)$, as given in Table 4 . 


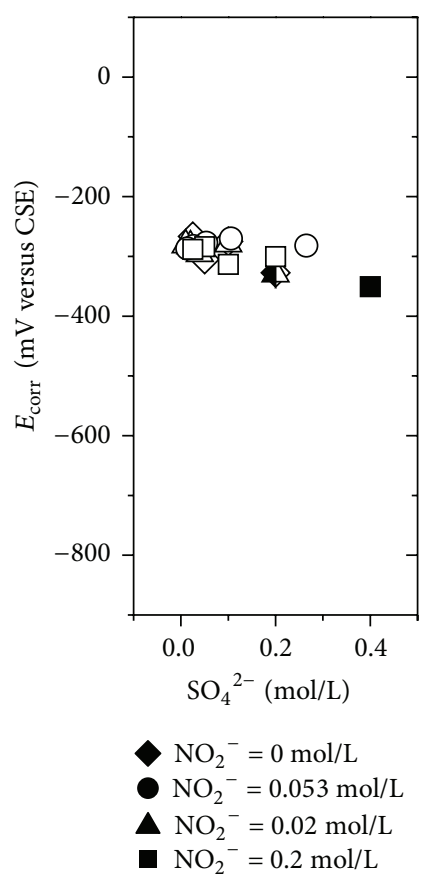

(a)

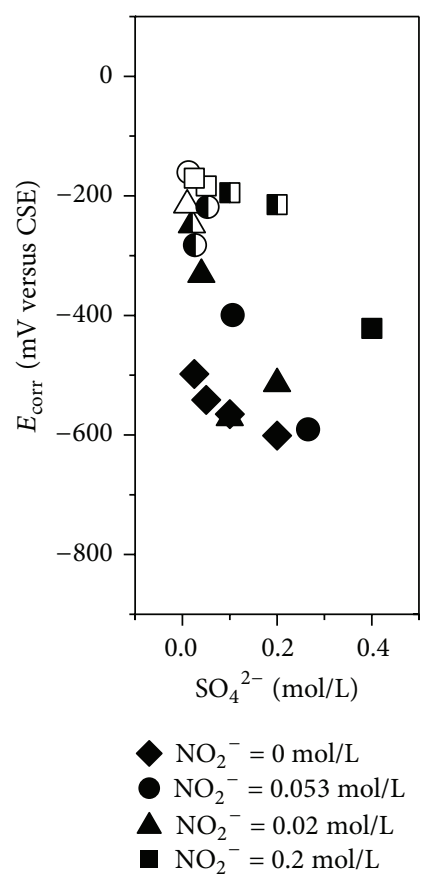

(b)

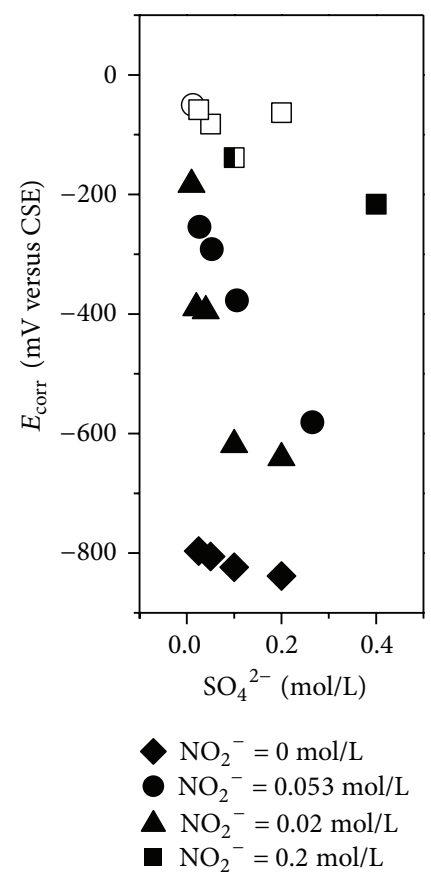

(c)

FIGURE 5: Effect of $\mathrm{NO}_{2}{ }^{-}$and $\mathrm{pH}$ on $E_{\text {corr }}$ induced by $\mathrm{SO}_{4}{ }^{2-}$. (a) $\mathrm{pH}=12.6$, (b) $\mathrm{pH}=10.3$, and (c) $\mathrm{pH}=8.1$.

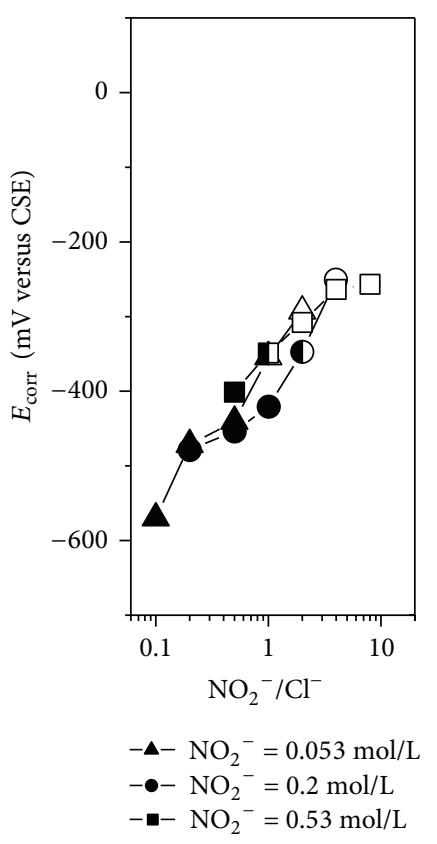

(a)

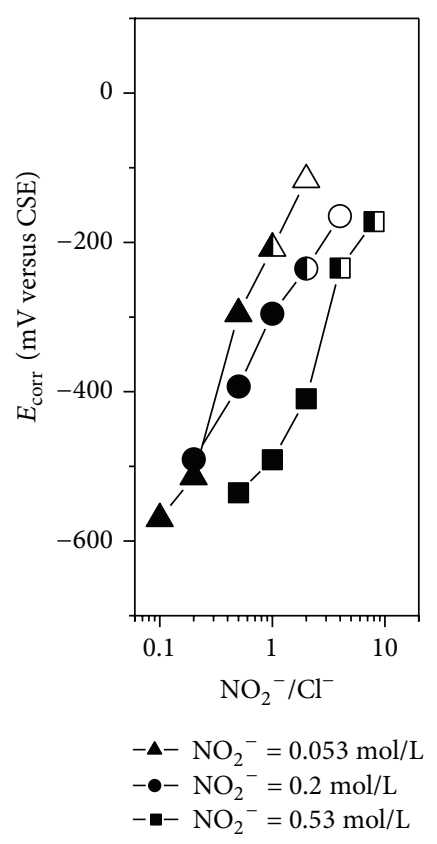

(b)

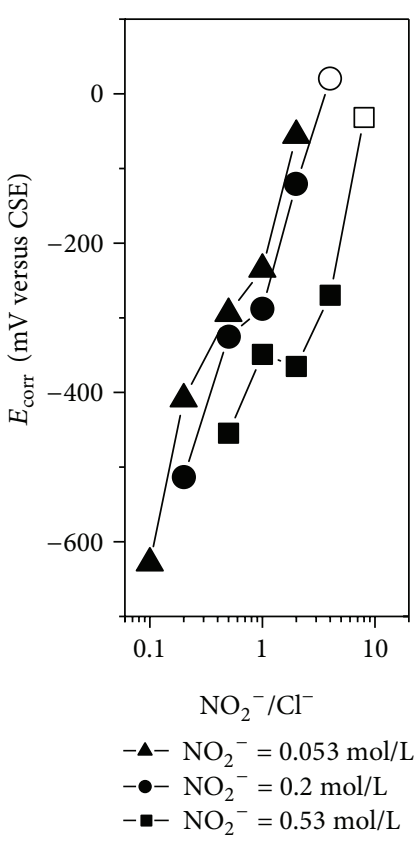

(c)

FIgURE 6: Effect of $\mathrm{NO}_{2}{ }^{-}$on $E_{\text {corr }}$ versus $\log \left(\mathrm{NO}_{2}{ }^{-} / \mathrm{Cl}^{-}\right)$curves. (a) $\mathrm{pH}=12.6$, (b) $\mathrm{pH}=10.3$, and (c) $\mathrm{pH}=8.1$.

3.4. Relationship between $\mathrm{E}_{\text {corr }}$ and $\mathrm{NO}_{2}{ }^{-} / \mathrm{SO}_{4}{ }^{2-}$. The relationship between $E_{\text {corr }}$ and $\log \left(\mathrm{NO}_{2}{ }^{-} / \mathrm{SO}_{4}{ }^{2-}\right)$ shown in Figure 7 indicates that, in $\mathrm{pH} 12.6$ environment, the mole ratio of $\mathrm{NO}_{2}{ }^{-} / \mathrm{SO}_{4}{ }^{2-}$ had little influence on $E_{\text {corr }}$, while in $\mathrm{pH} 10.3$ and $\mathrm{pH} 8.1$ environments, $E_{\text {corr }}$ increased with the increasing of $\mathrm{NO}_{2}{ }^{-} / \mathrm{SO}_{4}{ }^{2-}$ mole ratio. For sulfate-induced corrosion, the nitrite concentration almost had no influence on the curve of $E_{\text {corr }}$ versus $\log \left(\mathrm{NO}_{2}{ }^{-} / \mathrm{SO}_{4}{ }^{2-}\right)$, which was completely different from the condition for chlorideinduced corrosion. The linear relationship between $E_{\text {corr }}$ and $\log \left(\mathrm{NO}_{2}{ }^{-} / \mathrm{SO}_{4}{ }^{2-}\right)$ was shown in Table 5.

3.5. Threshold Level of $\mathrm{NO}_{2}{ }^{-} / \mathrm{Cl}^{-}$. Figure 8 presents the effect of nitrite concentration and $\mathrm{pH}$ on the threshold level of 
TABLE 4: Relationship between $E_{\text {corr }}$ and $\log \left(\mathrm{NO}_{2}{ }^{-} / \mathrm{Cl}^{-}\right)$.

\begin{tabular}{|c|c|c|c|c|c|}
\hline \multirow{2}{*}{$\mathrm{NO}_{2}{ }^{-} \mathrm{mol} / \mathrm{L}$} & \multirow{2}{*}{$\mathrm{pH}$} & \multirow{2}{*}{$E_{F}, \mathrm{mV}$ versus CSE } & \multicolumn{3}{|c|}{$E_{\text {corr }}=a * \log \left(\mathrm{NO}_{2}^{-} / \mathrm{Cl}^{-}\right)+b$} \\
\hline & & & $a$ & $b$ & $R^{2}$ \\
\hline 0.053 & 12.58 & -342.5 & 201.9 & -357.2 & 0.97 \\
\hline 0.2 & 12.72 & -351.4 & 172.6 & -386.9 & 0.90 \\
\hline 0.53 & 12.71 & -350.7 & 124.3 & -353.1 & 0.95 \\
\hline 0.053 & 10.13 & -188.2 & 370.2 & -215.1 & 0.98 \\
\hline 0.2 & 10.24 & -195.1 & 253.0 & -310.9 & 0.995 \\
\hline 0.53 & 10.14 & -188.8 & 326.5 & -466.8 & 0.96 \\
\hline 0.053 & 7.88 & -46.4 & 398.0 & -189.3 & 0.96 \\
\hline 0.2 & 8.26 & -70.4 & 396.7 & -237.7 & 0.98 \\
\hline 0.53 & 8.42 & -80.5 & 307.4 & -386.6 & 0.83 \\
\hline
\end{tabular}

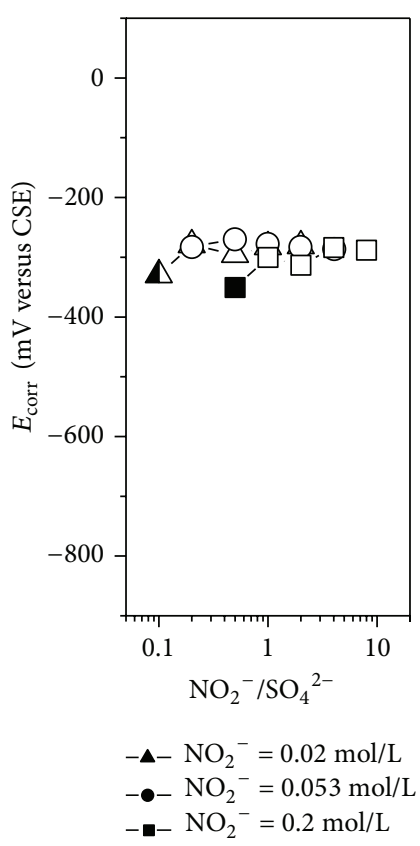

(a)

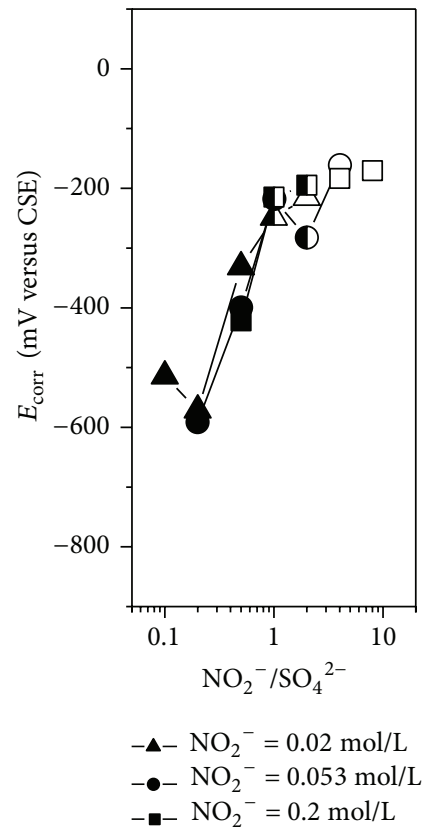

(b)

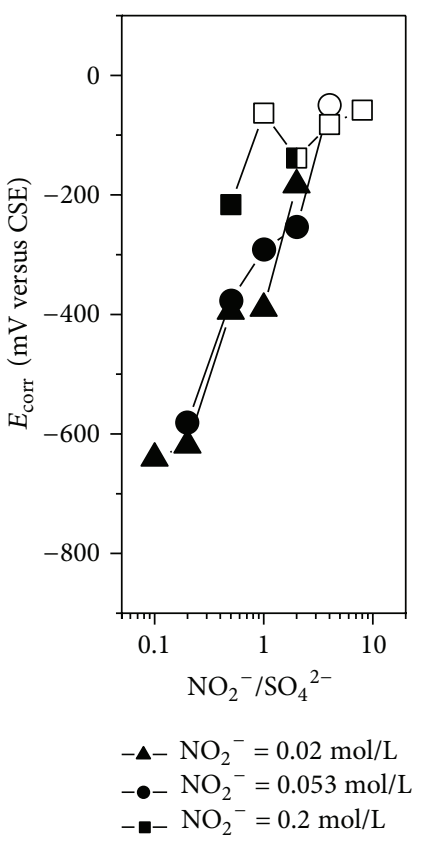

(c)

FIGURE 7: Effect of $\mathrm{NO}_{2}{ }^{-}$on $E_{\text {corr }}$ versus $\log \left(\mathrm{NO}_{2}{ }^{-} / \mathrm{SO}_{4}{ }^{2-}\right.$ ) curves. (a) $\mathrm{pH}=12.6$, (b) $\mathrm{pH}=10.3$, (c) $\mathrm{pH}=8.1$.

$\mathrm{NO}_{2}{ }^{-} / \mathrm{Cl}^{-}$that was determined by using the $E_{F}$ and the relationship between $E_{\text {corr }}$ and $\log \left(\mathrm{NO}_{2}{ }^{-} / \mathrm{Cl}^{-}\right)$as shown in Table 4. In $\mathrm{pH} 12.6$ environment, nitrite concentration almost had no influence on the threshold level of $\mathrm{NO}_{2}{ }^{-} / \mathrm{Cl}^{-}$, while in $\mathrm{pH} 10.3$ and $\mathrm{pH} 8.1$ environments, the threshold level increased with the increasing of nitrite concentration. The constant of the threshold level of $\mathrm{NO}_{2}{ }^{-} / \mathrm{Cl}^{-}$in $\mathrm{pH}$ 12.6 environment means that $\mathrm{NO}_{2}{ }^{-} / \mathrm{Cl}^{-}$mole ratio can be performed as the parameter to evaluate the corrosion of steel in highly alkaline environment, but it is not suitable for the situation in weakly alkaline and neutral environments because the threshold level of $\mathrm{NO}_{2}{ }^{-} / \mathrm{Cl}^{-}$changed greatly with different nitrite concentrations.
3.6. Threshold Level of $\mathrm{NO}_{2}{ }^{-} / \mathrm{SO}_{4}{ }^{2-}$. In the $\mathrm{NO}_{2}{ }^{-} / \mathrm{Cl}^{-}$system, there was a good linear relationship between $E_{\text {corr }}$ and $\log \left(\mathrm{NO}_{2}{ }^{-} / \mathrm{Cl}^{-}\right)$for each nitrite concentration in $\mathrm{pH} 12.6$, $\mathrm{pH} 10.3$, and $\mathrm{pH} 8.1$ environments, but in $\mathrm{NO}_{2}{ }^{-} / \mathrm{SO}_{4}{ }^{2-}$ system, the good linear relationship between $E_{\text {corr }}$ and $\log \left(\mathrm{NO}_{2}{ }^{-} / \mathrm{SO}_{4}{ }^{2-}\right)$ only can be found in $\mathrm{pH} 8.1$ and $\mathrm{pH}$ 10.3 environments with 0.02 and $0.053 \mathrm{~mol} / \mathrm{L} \mathrm{NO}_{2}{ }^{-}$. So the threshold level of $\mathrm{NO}_{2}{ }^{-} / \mathrm{SO}_{4}{ }^{2-}$ in $\mathrm{pH} 8.1$ and $\mathrm{pH} 10.3$ environments with 0.02 and $0.053 \mathrm{~mol} / \mathrm{L} \mathrm{NO}_{2}{ }^{-}$was obtained by using the $E_{F}$ and the relationship between $E_{\text {corr }}$ and $\log \left(\mathrm{NO}_{2}{ }^{-}\right.$/ $\mathrm{SO}_{4}{ }^{2-}$ ) as shown in Table 5, while the threshold levels of $\mathrm{NO}_{2}{ }^{-} / \mathrm{SO}_{4}{ }^{2-}$ in $\mathrm{pH} 12.6$ environment with $0.02,0.053$, and $0.2 \mathrm{~mol} / \mathrm{L} \mathrm{NO}_{2}{ }^{-}$and in $\mathrm{pH} 8.1$ and $\mathrm{pH} 10.3$ environments 
TABLE 5: Relationship between $E_{\text {corr }}$ and $\log \left(\mathrm{NO}_{2}{ }^{-} / \mathrm{SO}_{4}{ }^{2-}\right)$.

\begin{tabular}{|c|c|c|c|c|c|}
\hline \multirow{2}{*}{$\mathrm{NO}_{2}{ }^{-} \mathrm{mol} / \mathrm{L}$} & \multirow{2}{*}{$\mathrm{pH}$} & \multirow{2}{*}{$E_{F}, \mathrm{mV}$ versus CSE } & \multicolumn{3}{|c|}{$E_{\text {corr }}=a * \log \left(\mathrm{NO}_{2}^{-} / \mathrm{SO}_{4}{ }^{2-}\right)+b$} \\
\hline & & & $a$ & $b$ & $R^{2}$ \\
\hline 0.02 & 12.6 & -330 & 27.9 & -284.1 & 0.47 \\
\hline 0.053 & 12.6 & -330 & -6.3 & -279.8 & 0.25 \\
\hline 0.2 & 12.6 & -330 & 47.0 & -321.4 & 0.69 \\
\hline 0.02 & 10.1 & -205 & 283.1 & -280.2 & 0.87 \\
\hline 0.053 & 10.1 & -205 & 310.3 & -324.3 & 0.85 \\
\hline 0.2 & 10.1 & -205 & 177.3 & -290.4 & 0.65 \\
\hline 0.02 & 8.26 & -113 & 347.6 & -327.5 & 0.93 \\
\hline 0.053 & 8.26 & -113 & 371.4 & -303.7 & 0.96 \\
\hline 0.2 & 8.1 & -105 & 98.7 & -141.4 & 0.50 \\
\hline
\end{tabular}

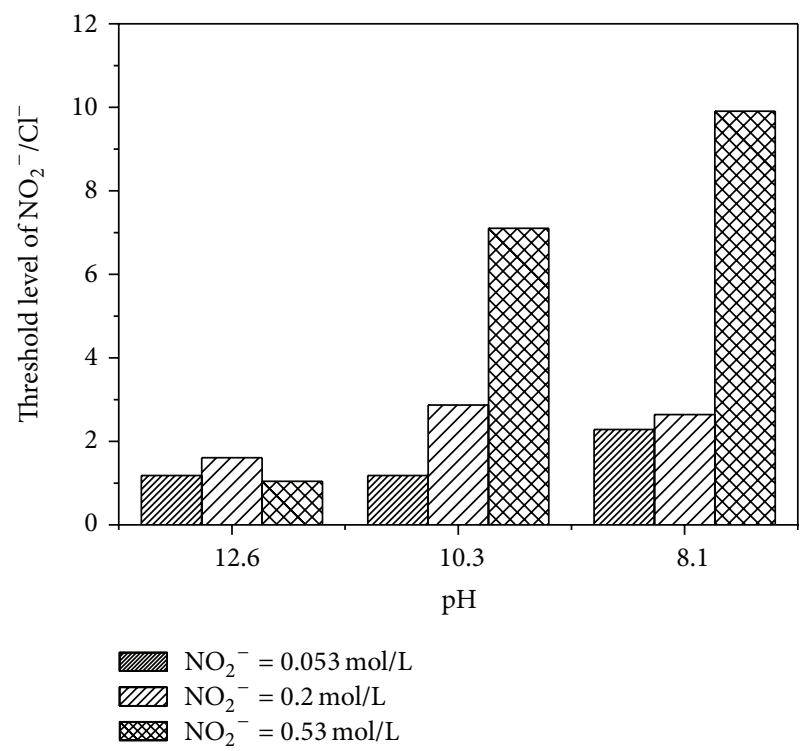

Figure 8: Effect of $\mathrm{NO}_{2}{ }^{-}$on the threshold values of $\mathrm{NO}_{2}{ }^{-} / \mathrm{Cl}^{-}$.

with $0.2 \mathrm{~mol} / \mathrm{L} \mathrm{NO}_{2}{ }^{-}$were judged according to the results of corrosion judgment as described in Table 3 and shown in Figure 7. The threshold levels of $\mathrm{NO}_{2}{ }^{-} / \mathrm{SO}_{4}{ }^{2-}$ obtained here might be not accurate, but they were well consistent with the experimental results and could provide some information on the influence of nitrite concentrations.

Figure 9 presents the effect of nitrite concentrations and $\mathrm{pH}$ values on the threshold levels of $\mathrm{NO}_{2}{ }^{-} / \mathrm{SO}_{4}{ }^{2-}$. It can be seen that the threshold value of $\mathrm{NO}_{2}{ }^{-} / \mathrm{SO}_{4}{ }^{2-}$ was greatly influenced by $\mathrm{pH}$ values and nitrite concentrations and decreased with the increasing of $\mathrm{pH}$ values. In $\mathrm{pH}$ 8.1 environments, this threshold value decreased with the increasing of nitrite content, while in $\mathrm{pH} 10.3$ environments, it showed the opposite trend, increased with the increasing of nitrite content. In $\mathrm{pH} 12.6$ environments, the threshold value of $\mathrm{NO}_{2}{ }^{-} / \mathrm{SO}_{4}{ }^{2-}$ was $0.2,0.2$, and 0.656 for $0.02,0.053$, and $0.2 \mathrm{~mol} / \mathrm{L}$ nitrite, respectively. The change of the threshold value in these $\mathrm{pH}$ environments means that it cannot be used

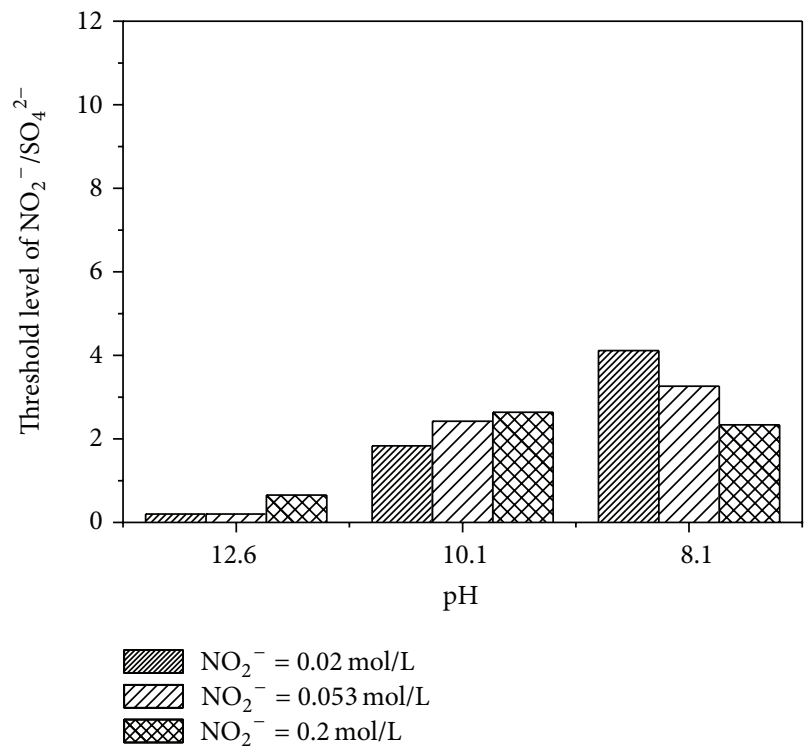

FIGURE 9: Effect of $\mathrm{NO}_{2}{ }^{-}$on the threshold values of $\mathrm{NO}_{2}{ }^{-} / \mathrm{SO}_{4}{ }^{2-}$.

as the parameter to evaluate the inhibiting efficiency of nitrite on sulfate-induced corrosion.

3.7. Threshold Level of $\mathrm{Cl}^{-}$. The effect of nitrite concentration and $\mathrm{pH}$ on the threshold level of chloride is shown in Figure 10. In pH 12.6 environment, the chloride threshold level increased markedly when the concentration of nitrite was raised from $0 \mathrm{~mol} / \mathrm{L}$ to $0.53 \mathrm{~mol} / \mathrm{L}$, while in $\mathrm{pH} 10.3$ and $\mathrm{pH} 8.1$ environments, if the concentration of nitrite was less than $0.2 \mathrm{~mol} / \mathrm{L}$, the chloride threshold level had an increasing trend, and if the nitrite content was higher than $0.2 \mathrm{~mol} / \mathrm{L}$, there was almost no increase in the chloride threshold level, even the decrease could also be found with the experimental results. The chloride threshold level in $\mathrm{pH} 12.6$ environment was greater than that in $\mathrm{pH} 10.3$ and $\mathrm{pH} 8.1$ environments, especially for the presence of higher nitrite concentration, indicating that the highly alkaline environment played an important role in assisting nitrite to increase the chloride threshold level. The combined effect of $\mathrm{OH}^{-}$and $\mathrm{NO}_{2}{ }^{-}$on 


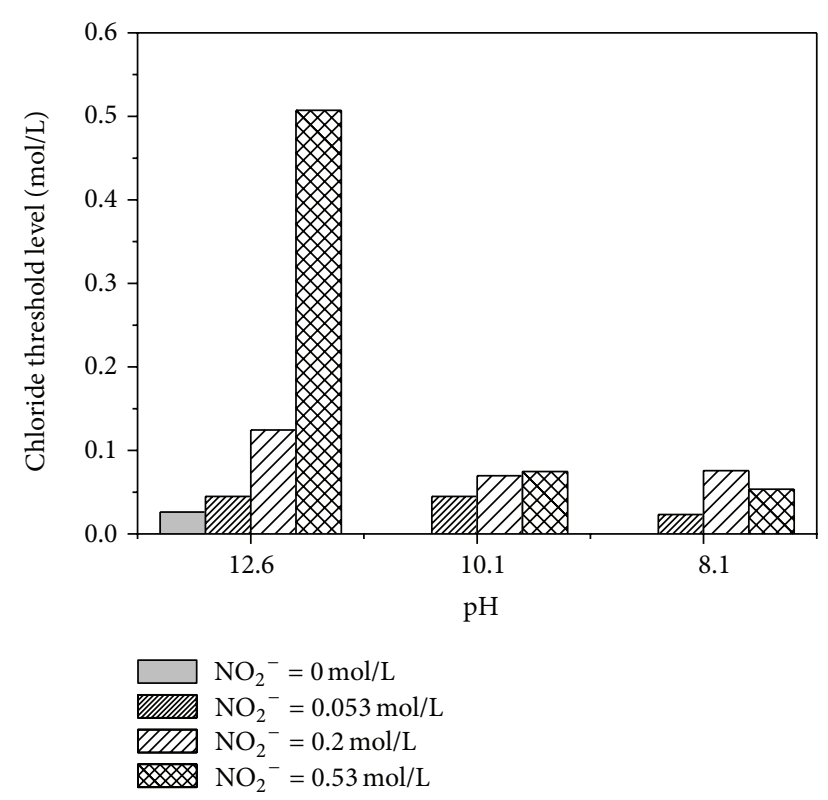

Figure 10: Effect of $\mathrm{NO}_{2}{ }^{-}$on the threshold values of $\mathrm{Cl}^{-}$.

inhibiting corrosion was superior to the individual effect. However, the use of $\mathrm{NO}_{2}{ }^{-} / \mathrm{Cl}^{-}$mole ratio as the parameter to guarantee the inhibition efficiency did not take into account the effect of $\mathrm{OH}^{-}$. So whether $\mathrm{NO}_{2}{ }^{-} / \mathrm{Cl}^{-}$is the most suitable parameter to evaluate chloride-induced corrosion in highly alkaline environments is worthy of further study. Besides this, why the inhibiting efficiency of nitrite on steel corrosion in neutral environment is weakened should be further investigated. The results obtained in this study are mainly based on the methods of half-cell potential and visual examination; they should be further confirmed by corrosion current measurement.

3.8. Threshold Level of $\mathrm{SO}_{4}{ }^{2-}$. The effect of nitrite concentration and $\mathrm{pH}$ on the threshold level of sulfate was given in Figure 11. As Seen from the figure, irrespective of the $\mathrm{pH}$ values, with the increasing of nitrite concentration, the sulfate threshold level increased significantly. For the same nitrite content, sulfate threshold level in $\mathrm{pH} 12.6$ environments was much greater than that in $\mathrm{pH} 10.3$ and $\mathrm{pH} 8.1$ environments. So the highly alkaline environment played an important role in assisting nitrite to increase the sulfate threshold level.

3.9. Comparing the $\mathrm{E}_{\text {corr }}$ Induced by $\mathrm{Cl}^{-}$and $\mathrm{SO}_{4}{ }^{2-}$. Figure 12 compares the $E_{\text {corr }}$ induced by $\mathrm{Cl}^{-}$and $\mathrm{SO}_{4}{ }^{2-}$ in three $\mathrm{pH}$ environments containing $0,0.053$, and $0.2 \mathrm{~mol} / \mathrm{L} \mathrm{NO}_{2}^{-}$. It can be seen that, in $\mathrm{pH} 10.3$ and $\mathrm{pH} 8.1$ environments with 0 and $0.053 \mathrm{~mol} / \mathrm{L} \mathrm{NO}_{2}{ }^{-}$, when $\mathrm{SO}_{4}{ }^{2-}$ content was equal to $\mathrm{Cl}^{-}$content, the $E_{\text {corr }}$ resulted from sulfate-induced corrosion was lower than that resulted from chloride-induced corrosion. The corrosivity of sulfate was stronger than that of chloride in this condition. However, there was a dramatic change after the content of nitrite was raised to $0.2 \mathrm{~mol} / \mathrm{L}$ $\mathrm{NO}_{2}{ }^{-}$; the $E_{\text {corr }}$ in sulfate environment was higher than that

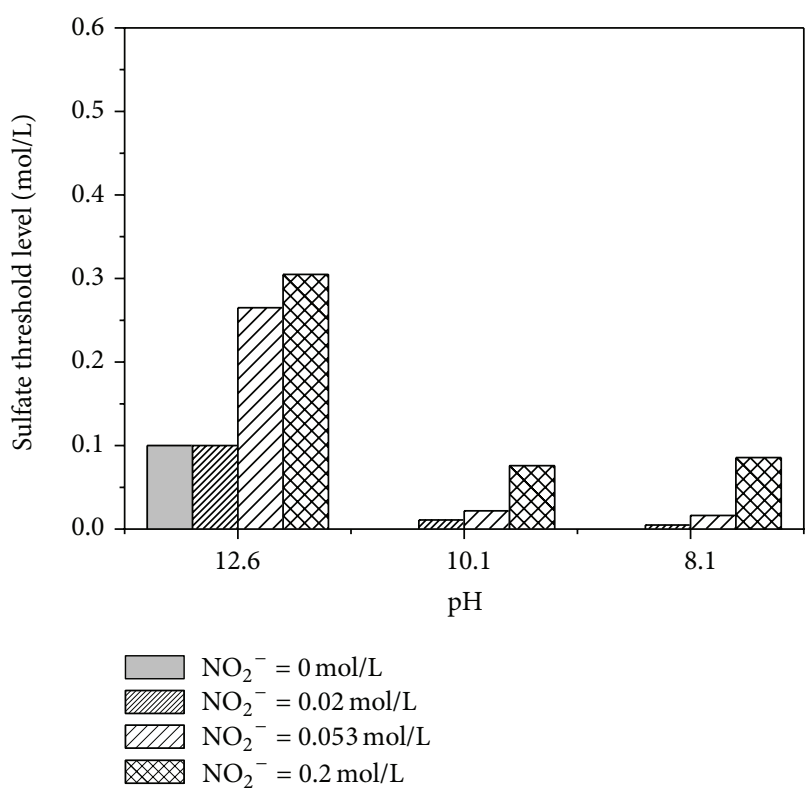

Figure 11: Effect of $\mathrm{NO}_{2}{ }^{-}$on the threshold values of $\mathrm{SO}_{4}{ }^{2-}$.

in chloride environment and the corrosion extent of steel immersed in sulfate environment was greatly reduced. In $\mathrm{pH}$ 12.6 environment, regardless of the absence or the presence of nitrite, the $E_{\text {corr }}$ resulted from sulfate-induced corrosion was higher than that resulted from chloride-induced corrosion, and almost all specimens were in passivation state when sulfate ions were equal to or less than $0.2 \mathrm{~mol} / \mathrm{L}$. So the corrosivity of sulfate ions on steel in $\mathrm{pH} 12.6$ environment was weaker than that of chloride. From the above analysis, a conclusion could be obtained that the corrosivity of sulfate against chloride was variable and greatly affected by the value of $\mathrm{pH}$ and the concentrations of nitrite.

3.10. Comparing the Threshold Level of $\mathrm{Cl}^{-}$and $\mathrm{SO}_{4}{ }^{2-}$. The threshold level of $\mathrm{Cl}^{-}$and the threshold level of $\mathrm{SO}_{4}{ }^{2-}$ were compared and analyzed in $\mathrm{pH} 12.6, \mathrm{pH} 10.3$ and $\mathrm{pH}$ 8.1 environments containing $0,0.053$, and $0.2 \mathrm{~mol} / \mathrm{L} \mathrm{NO}_{2}{ }^{-}$ respectively. The results were presented in Figure 13. In $\mathrm{pH} 12.6$ environment, whatever the concentration of nitrite was, sulfate threshold level was always higher than chloride threshold level under the same condition. This means that chloride-induced corrosion was more prone to initiate than sulfate-induced corrosion in highly alkaline environment. However, in $\mathrm{pH} 10.3$ and $\mathrm{pH} 8.1$ environments, with the presence of $0.053 \mathrm{~mol} / \mathrm{L}$ nitrite, the sulfate threshold level was lower than chloride threshold level, and after nitrite concentration increased to $0.2 \mathrm{~mol} / \mathrm{L}$, the sulfate threshold level became higher than chloride threshold level. This means that sulfate-induced corrosion was more likely to occur than chloride-induced corrosion in carbonated and neutral environments in which nitrite concentration was equal to or less than $0.053 \mathrm{~mol} / \mathrm{L}$. Whether sulfate threshold level was higher or lower than chloride threshold level in carbonated and neutral environments was determined by nitrite content. 


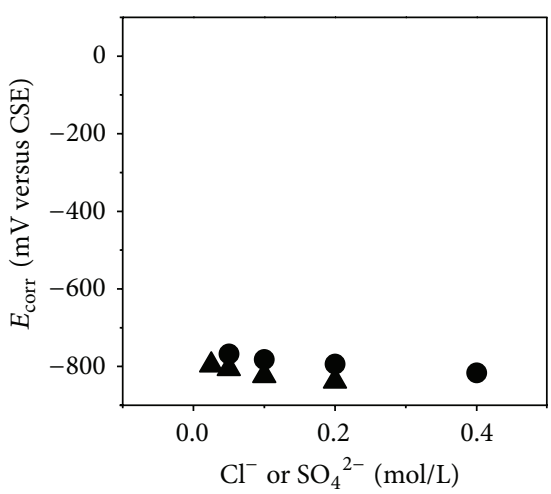

(a)

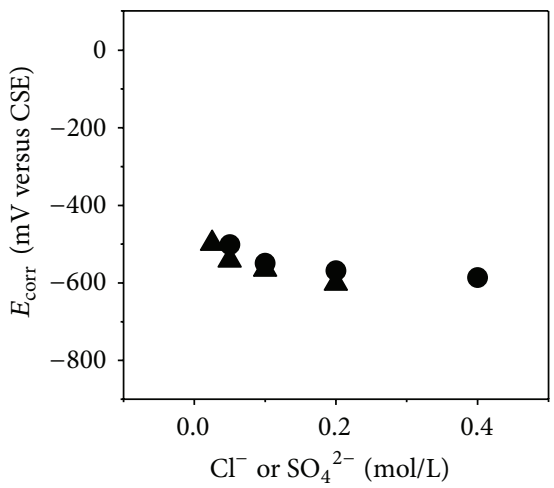

(d)

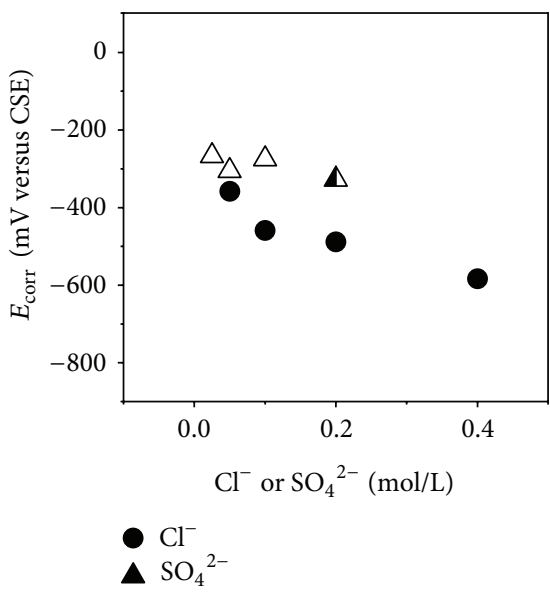

(g)

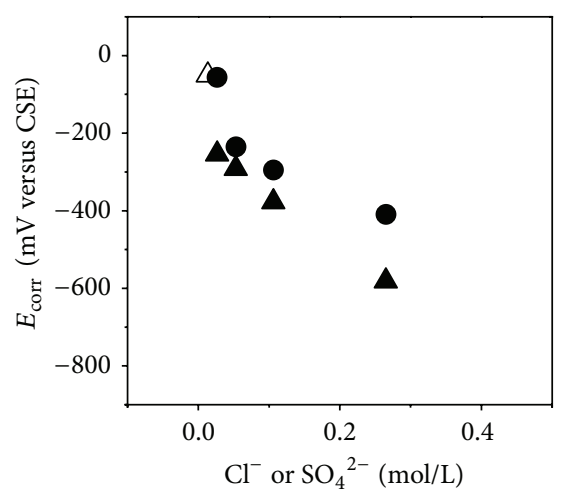

(b)

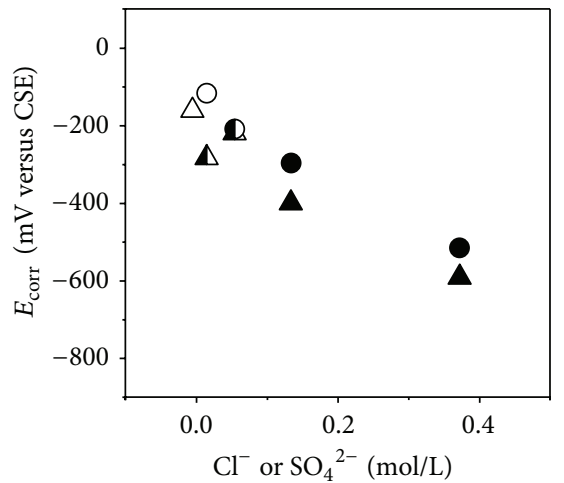

(e)

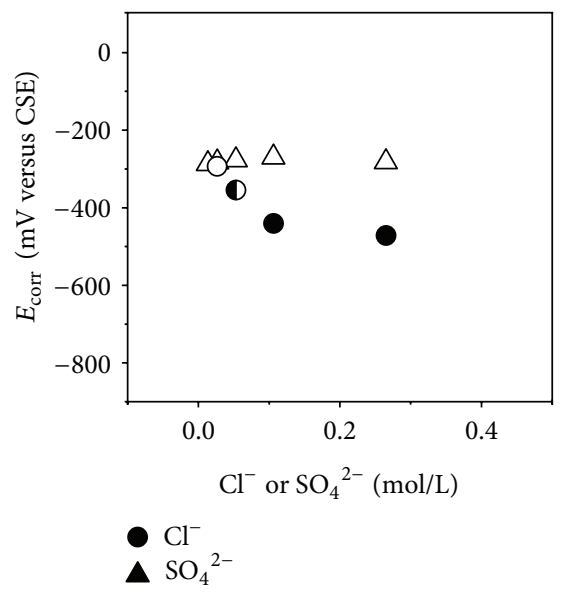

(h)

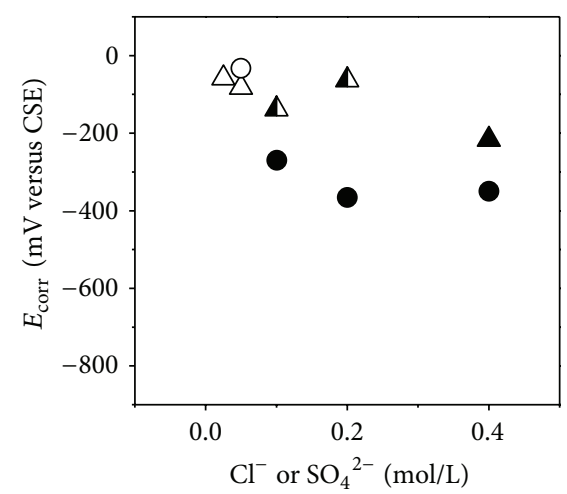

(c)

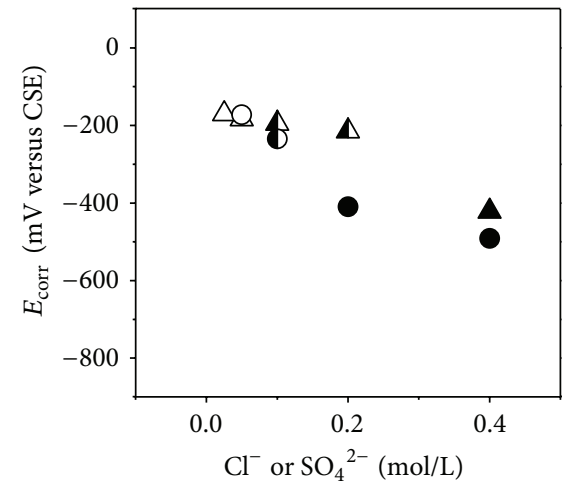

(f)

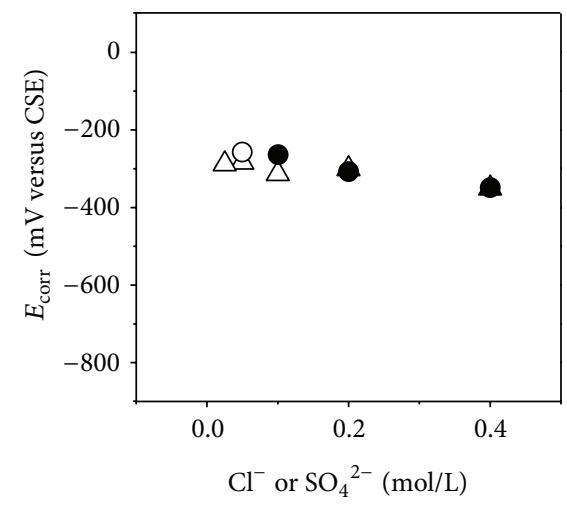

$\mathrm{Cl}^{-}$

(i)

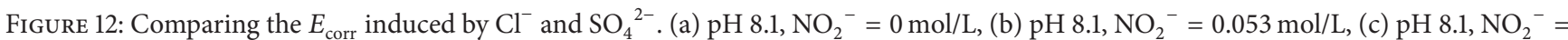
$0.2 \mathrm{~mol} / \mathrm{L}$, (d) $\mathrm{pH} 10.3, \mathrm{NO}_{2}{ }^{-}=0.0 \mathrm{~mol} / \mathrm{L}$, (e) $\mathrm{pH} 10.3, \mathrm{NO}_{2}^{-}=0.053 \mathrm{~mol} / \mathrm{L}$, (f) $\mathrm{pH} 10.3, \mathrm{NO}_{2}^{-}=0.2 \mathrm{~mol} / \mathrm{L},(\mathrm{g}) \mathrm{pH} 12.6, \mathrm{NO}_{2}^{-}=0.0 \mathrm{~mol} / \mathrm{L}$, (h) $\mathrm{pH} 12.6, \mathrm{NO}_{2}^{-}=0.053 \mathrm{~mol} / \mathrm{L}$, (i) $\mathrm{pH} 12.6, \mathrm{NO}_{2}{ }^{-}=0.2 \mathrm{~mol} / \mathrm{L}$.

So both $\mathrm{pH}$ and nitrite concentration had greater influence on chloride threshold level and sulfate threshold level.

3.11. Effect on Anodic/Cathodic Polarization Curves, Tafel Slope, and Stern-Geary Constant. Anodic/cathodic polarization curves of steel were obtained based on the method described above. After the cathodic (anodic) polarization, some changes might occur on the surface of steel and thus would have an influence on the further polarization of anodic (cathodic). In order to clarify this influence and give an answer to this problem, a preliminary experiment was carried out on the steel that had been immersed in distilled water for 3 days. Firstly, the cathodic polarization was done, and after finishing it, the steel was continued to be immersed in the solution about one day for the recovery of $E_{\text {corr }}$. And then, the anodic polarization was performed. The result was shown in Figure 14 and marked as black square "ø". After 


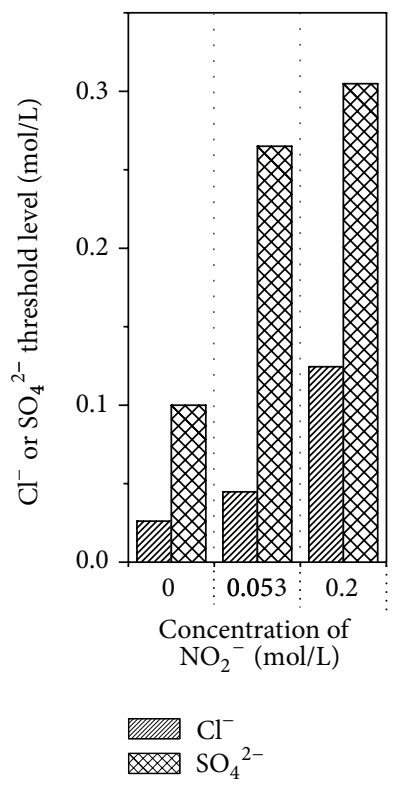

(a)

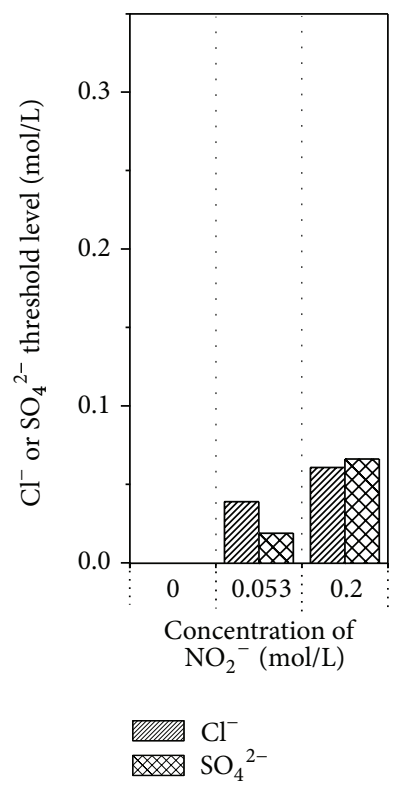

(b)

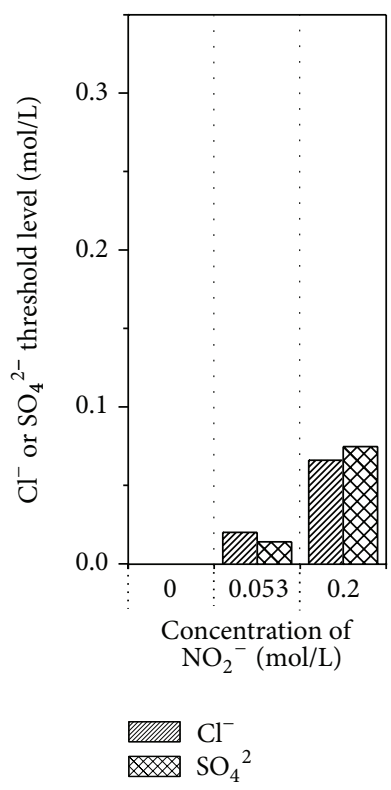

(c)

FIgURE 13: Comparing the threshold level of $\mathrm{Cl}^{-}$and $\mathrm{SO}_{4}{ }^{2-}$. (a) $\mathrm{pH}=12.6$, (b) $\mathrm{pH}=10.3$, and (c) $\mathrm{pH}=8.1$.

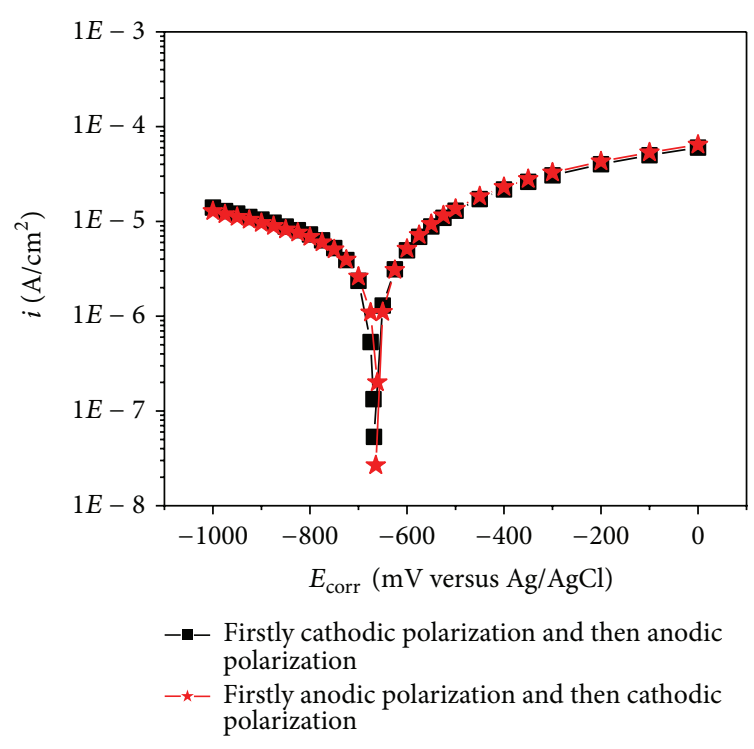

FIGURE 14: Polarization curves of steel immersed in distilled water for 3 days.

the cathodic and anodic polarization curves were obtained, the steel was continued to be immersed in the solution for the recovery of $E_{\text {corr. }}$. About three days later, the cathodic and anodic polarization were performed again, and this time, the anodic polarization was done firstly, and one day later, the cathodic polarization curve was obtained. The result was also presented in Figure 14 and marked as red star " $\star$ ”. Comparing the results, little difference can be observed from the two polarization curves. Some changes of the surface state of steel might occur after the cathodic (anodic) polarization, but after the recovery of $E_{\text {corr }}$, they were not enough to affect the further polarization of anodic (cathodic).

The effect of nitrite concentrations on the anodic and cathodic polarization curves, Tafel slope, and Stern-Geary constant $B$ in $\mathrm{pH} 12.6, \mathrm{pH} 10.3$, and $\mathrm{pH} 8.1$ environments with and without $0.1 \mathrm{~mol} / \mathrm{L} \mathrm{Cl}^{-}$or $\mathrm{SO}_{4}{ }^{2-}$ was shown in Figures 15 and 16 , respectively.

Steels immersed in $\mathrm{pH} 12.6$ environment without any chloride or sulfate (Figure 15(a)), and in the same solutions with $0.1 \mathrm{~mol} / \mathrm{L} \mathrm{SO}_{4}{ }^{2-}$ (Figure $15(\mathrm{~g})$ ) they were all in the passive state. With the presence of 0.02 and $0.2 \mathrm{~mol} / \mathrm{L}$ nitrite, both the $E_{\text {corr }}$ and polarization curves of steel did not show any obvious change. So the presence of nitrite had little influence on the anodic and cathodic polarization behaviors of steel. There was almost no change in $\beta_{a}, \beta_{c}$, and $B$ in these conditions (Figures 16(a), 16(d), and $16(\mathrm{~g})$ ). However, in $\mathrm{pH} 12.6$ environment with $0.1 \mathrm{~mol} / \mathrm{L} \mathrm{Cl}^{-}$(Figure $15(\mathrm{~d})$ ), the steel was corroded with the presence of 0 and $0.02 \mathrm{~mol} / \mathrm{L}$ nitrite and was in passive state when nitrite concentration was $0.2 \mathrm{~mol} / \mathrm{L}$. With the increase of nitrite concentration, there was almost no change in the cathodic polarization curve, but the anodic polarization curves moved toward the direction of lower current density. Corresponding to this, $\beta_{a}$ decreased, while $\beta_{c}$ remained constant, which resulted in the decrease of $B$ value as described in Figures 16(a), 16(d), and 16(g).

In $\mathrm{pH} 10.3$ environment without any $\mathrm{Cl}^{-}$or $\mathrm{SO}_{4}{ }^{2-}$ (Figure 15(b)), the steel was corroded with the absence of nitrite and was in passive state when nitrite concentration was 0.02 and $0.2 \mathrm{~mol} / \mathrm{L}$. With the increase of nitrite concentration, little difference in the cathodic polarization curves was observed. The presence of $0.02 \mathrm{~mol} / \mathrm{L}$ nitrite made the anodic polarization curves shift towards the direction of lower current density, but higher nitrite concentration $(0.2 \mathrm{~mol} / \mathrm{L})$ seemed to have no significant effect on the further decrease of 


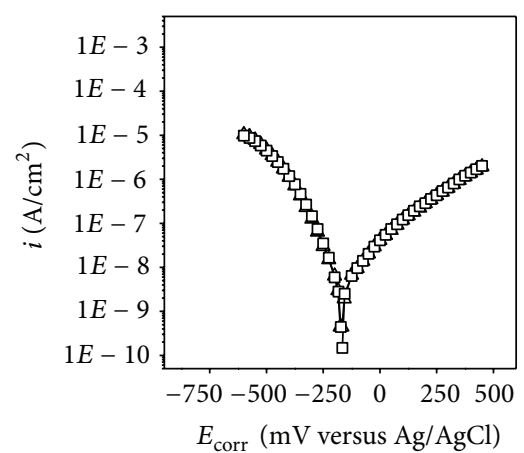

(a)

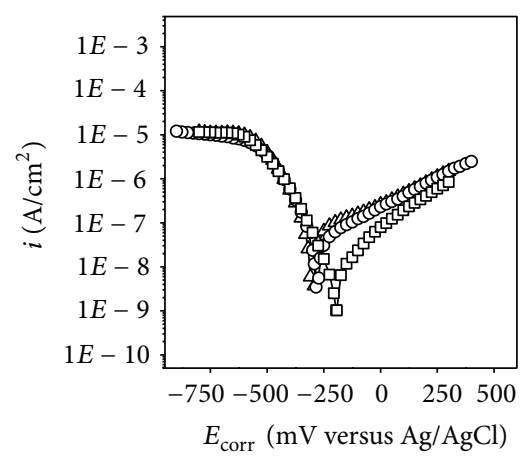

(d)

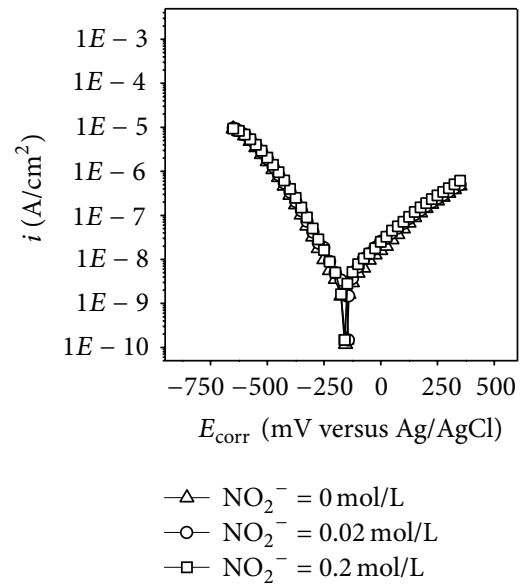

(g)

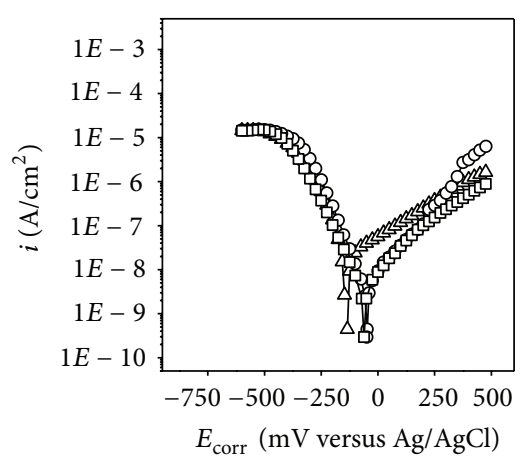

(b)

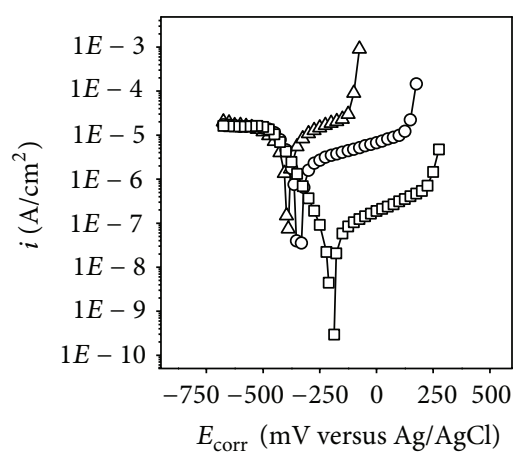

(e)

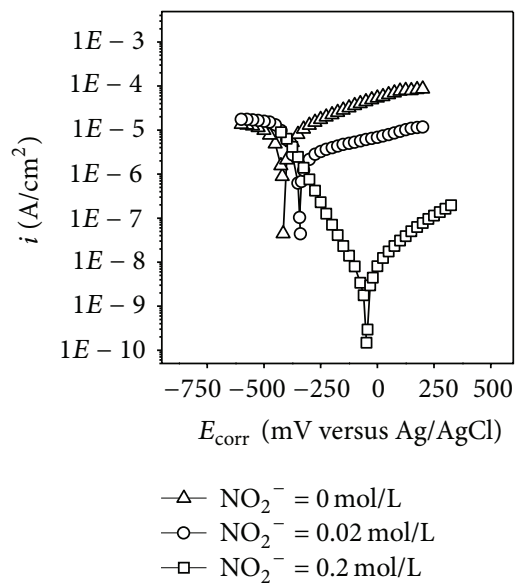

(h)

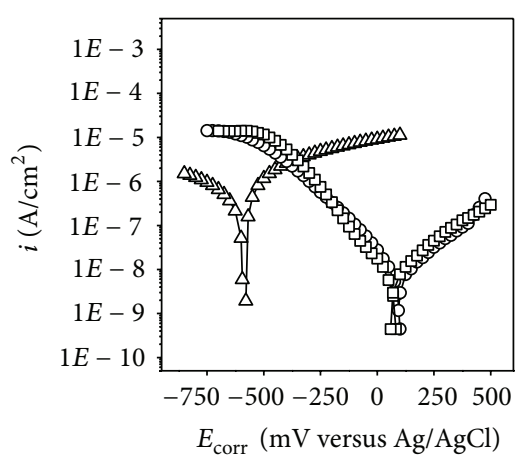

(c)

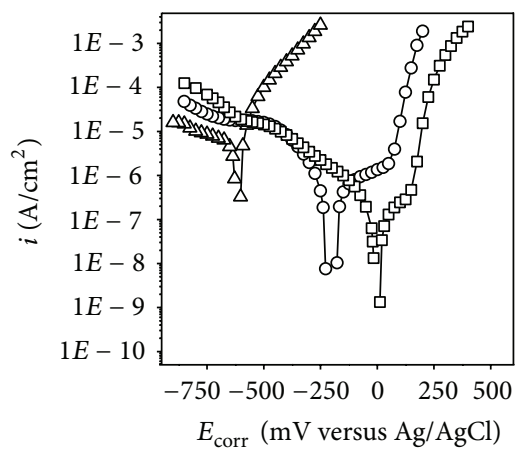

(f)

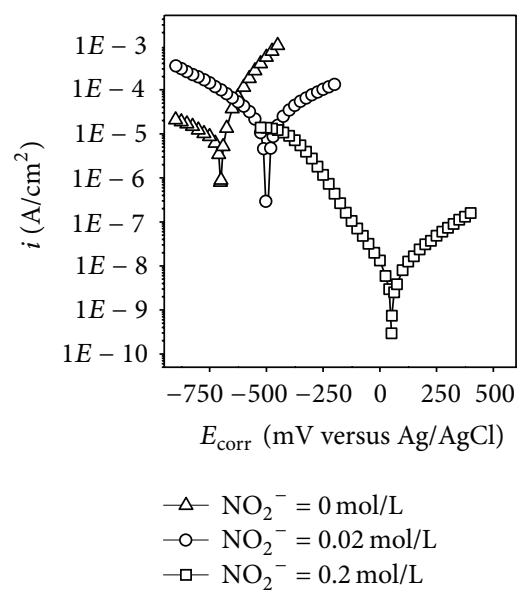

(i)

FIGURE 15: Effect of $\mathrm{NO}_{2}{ }^{-}$concentration on anodic and cathodic polarization curves of steel immersed in different $\mathrm{pH}$ solutions with and

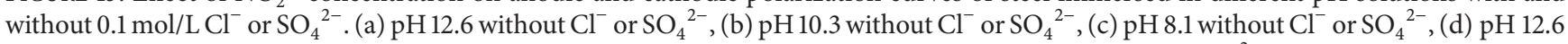
with $0.1 \mathrm{~mol} / \mathrm{L} \mathrm{Cl}^{-}$, (e) $\mathrm{pH} 10.3$ with $0.1 \mathrm{~mol} / \mathrm{L} \mathrm{Cl}^{-}$, (f) $\mathrm{pH} 8.1$ with $0.1 \mathrm{~mol} / \mathrm{L} \mathrm{Cl}^{-}$, (g) $\mathrm{pH} 12.6$ with $0.1 \mathrm{~mol} / \mathrm{L} \mathrm{SO}_{4}{ }^{2-}$, (h) $\mathrm{pH} 10.3 \mathrm{with} 0.1 \mathrm{~mol} / \mathrm{L}^{-}$ $\mathrm{SO}_{4}{ }^{2-}$, and (i) $\mathrm{pH} 8.1$ with $0.1 \mathrm{~mol} / \mathrm{L} \mathrm{SO}_{4}{ }^{2-}$.

current density of anodic polarization. Tafel slopes $\beta_{a}$ and $\beta_{c}$ and Stern-Geary constant $B$ all decreased with the presence of nitrite as presented in Figures 16(b), 16(e), and 16(h).

In $\mathrm{pH} 10.3$ environment with $0.1 \mathrm{~mol} / \mathrm{L} \mathrm{Cl}^{-}$(Figure $15(\mathrm{e})$ ), the steel was corroded seriously with the absence of nitrite. Upon increasing the potential above the self-potential, a passive region was found where the current density was of the order of $10^{-5} \mathrm{~A} / \mathrm{cm}^{2}$. At potential value higher than $-125 \mathrm{mV}$ versus $\mathrm{Ag} / \mathrm{AgCl}$, an abrupt increase in the current density was observed resulting from the onset of the oxygen evolution reaction. The anodic polarization curves obtained in the presence of $0.02 \mathrm{~mol} / \mathrm{L}$ nitrite were different from the one obtained in the absence of nitrite ions. The presence of higher nitrite contents had a substantial effect on the anodic behavior of the steel. The anodic polarization curves showed a passive zone, where the passive current density decreased with the increasing of nitrite concentrations. It was in the order of $10^{-6} \mathrm{~A} / \mathrm{cm}^{2}$ for $0.02 \mathrm{~mol} / \mathrm{L}$ nitrite and 


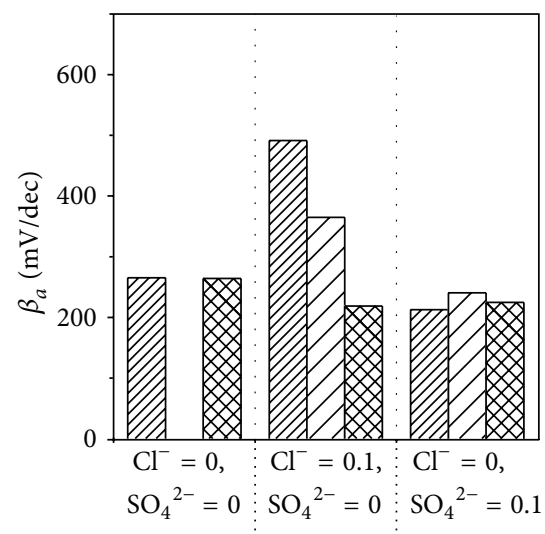

(a)

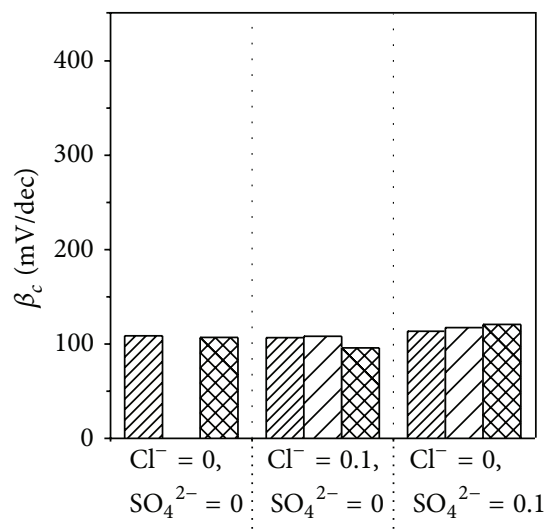

(d)

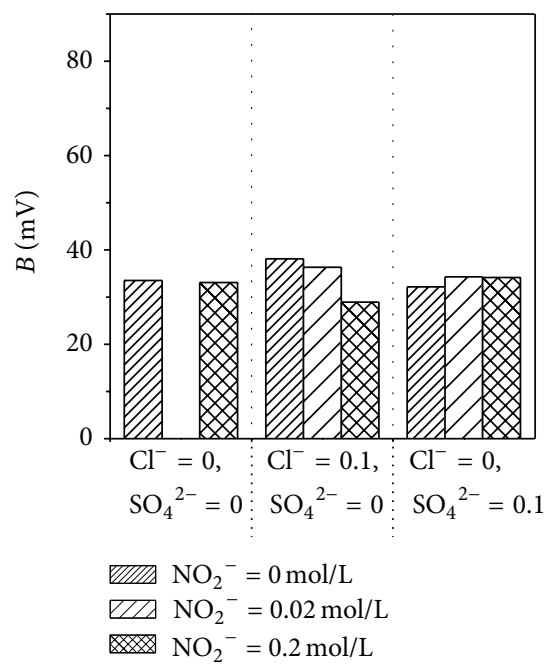

(g)

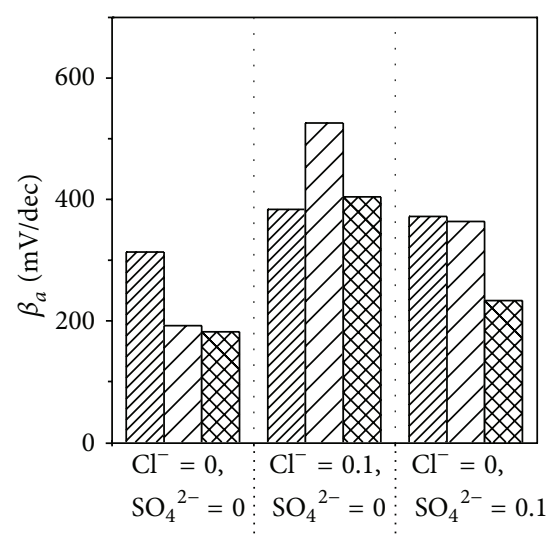

(b)

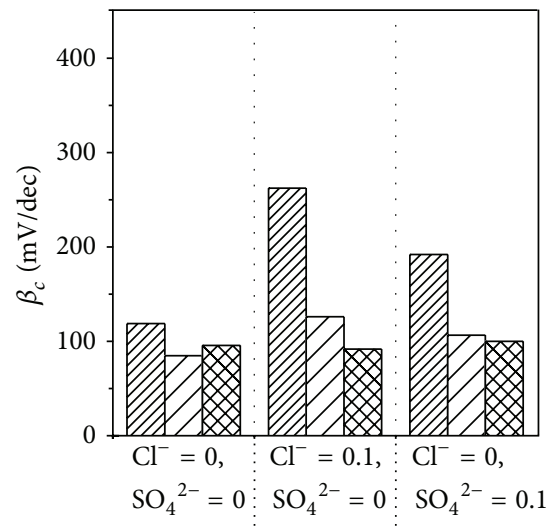

(e)

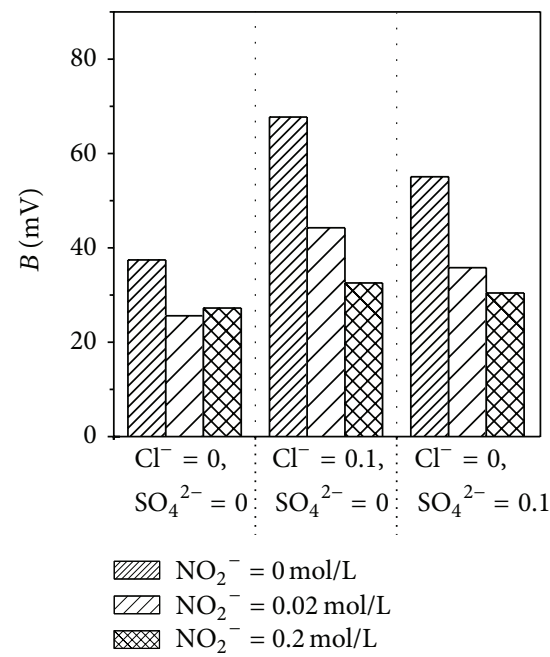

(h)

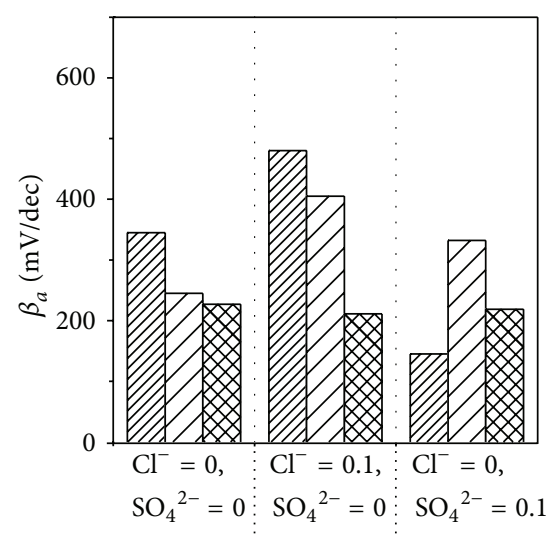

(c)

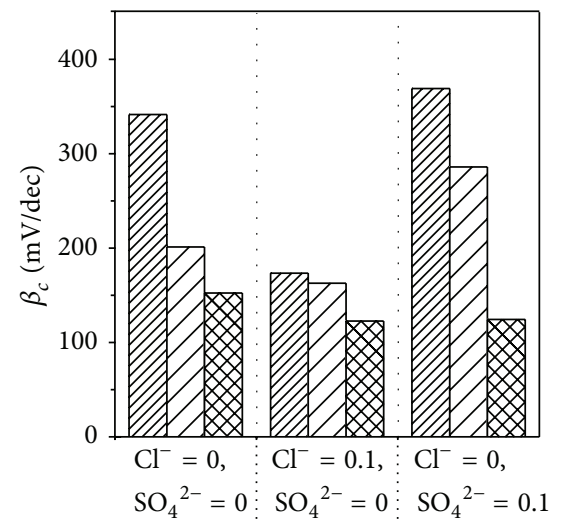

(f)

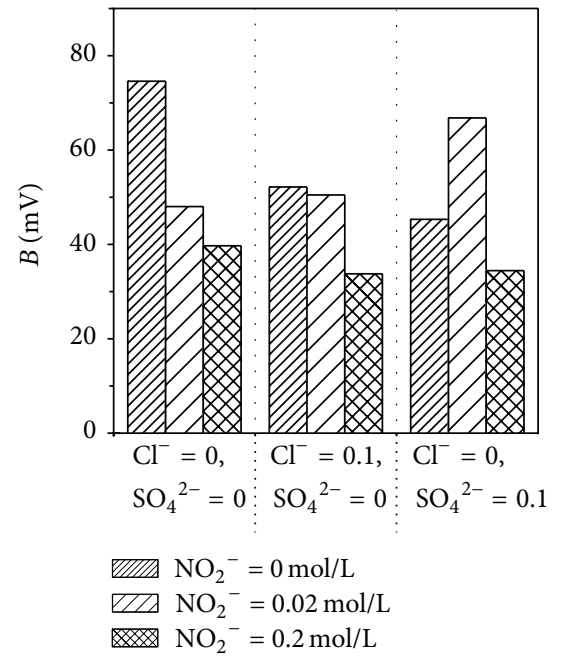

(i)

Figure 16: Effect of $\mathrm{NO}_{2}{ }^{-}$concentration on Tafel slope and Stern-Geary constant $B$. (a) $\beta_{a}$ in $\mathrm{pH} 12.6$, (b) $\beta_{a}$ in $\mathrm{pH} 10.3$, (c) $\beta_{a}$ in pH 8.1,

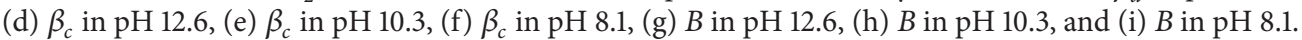

$10^{-7} \mathrm{~A} / \mathrm{cm}^{2}$ for $0.2 \mathrm{~mol} / \mathrm{L}$ nitrite. On the other hand, the passivity breakdown potential was observed and increased with the increasing of nitrite concentration. It was $125 \mathrm{mV}$ for $0.02 \mathrm{~mol} / \mathrm{L}$ nitrite and $225 \mathrm{mV}$ for $0.2 \mathrm{~mol} / \mathrm{L}$ nitrite. Besides this, Tafel slopes $\beta_{a}$ and $\beta_{c}$ and Stern-Geary constant $B$ were greatly influenced by the nitrite concentration. The value of $\beta_{c}$ and $B$ decreased with the increasing of nitrite concentration. The $B$ value with $0 \mathrm{~mol} / \mathrm{L}$ nitrite was almost twice that with $0.2 \mathrm{~mol} / \mathrm{L}$ nitrite as shown in Figures 16(b), 16(e), and 16(h).

In $\mathrm{pH} \quad 10.3$ environment with $0.1 \mathrm{~mol} / \mathrm{L}_{4} \quad \mathrm{SO}_{4}{ }^{2-}$ (Figure 15(h)), with the absence of nitrite, the steel was corroded. As the potential was raised from the self-potential, 
the current density increased with the potential and attained a value of the order of $10^{-4} \mathrm{~A} / \mathrm{cm}^{2}$. No breakdown potential was observed even when the potential reached $200 \mathrm{mV}$ versus $\mathrm{Ag} / \mathrm{AgCl}$. The presence of 0.02 and $0.2 \mathrm{~mol} / \mathrm{L}$ nitrite ions not only shifted the self-potential toward higher values but also decreased the current density of anodic and cathodic polarization in the condition of the same over potential. The higher the nitrite concentration, the lower the current density of anodic and cathodic polarization. In this case, both Tafel slopes $\beta_{a}$ and $\beta_{c}$ and Stern-Geary constant $B$ decreased with the presence of nitrite as given in Figures 16(b), 16(e), and 16(h).

In $\mathrm{pH} 8.1$ environment without any $\mathrm{Cl}^{-}$or $\mathrm{SO}_{4}{ }^{2-}$ (Figure 15(c)), the steel was corroded seriously with the absence of nitrite, and it was in passive state when nitrite concentration was 0.02 and $0.2 \mathrm{~mol} / \mathrm{L}$. The presence of low content of nitrite $(0.02 \mathrm{~mol} / \mathrm{L})$ not only greatly raised the steel potential and reduced the current density of anodic polarization but also markedly decreased the current density of cathodic polarization. Under the same over potential, the cathodic polarization current density obtained in the solution containing $0.02 \mathrm{~mol} / \mathrm{L}$ nitrite was about one order of magnitude lower than that obtained in the absence of nitrite, and further increase of nitrite concentration $(0.2 \mathrm{~mol} / \mathrm{L}) \mathrm{did}$ not result in the further decrease of current density of cathodic polarization. In this case, Tafel slopes $\beta_{a}$ and $\beta_{c}$ and Stern-Geary constant $B$ decreased with the presence of nitrite as presented in Figures 16(c), 16(f), and 16(i).

In $\mathrm{pH} 8.1$ environment with $0.1 \mathrm{~mol} / \mathrm{L} \mathrm{Cl}^{-}$(Figure 15(f)), the steel was corroded seriously with the absence of nitrite. Upon increasing the potential above the self-potential, no passive region can be found. With the presence of nitrite, the self-potential shifted toward the positive directionand was function of nitrite concentration. The anodic polarization behavior of steel in $\mathrm{pH} 8.1$ environment containing $0.1 \mathrm{~mol} / \mathrm{L}$ $\mathrm{Cl}^{-}$and 0.02 or $0.2 \mathrm{~mol} / \mathrm{L} \mathrm{NO}_{2}{ }^{-}$was found to be similar to that observed in $\mathrm{pH} 10.3$ environment (Figure 15(e)). A passive region followed by an abrupt increase of current density at the potential higher than $50 \mathrm{mV}$ for $0.02 \mathrm{~mol} / \mathrm{L}$ nitrite or $150 \mathrm{mV}$ for $0.2 \mathrm{~mol} / \mathrm{L}$ nitrite was observed. The presence of nitrite also had an effect on the cathodic behavior of steel, which caused the cathodic polarization curve to shift to the direction of lower current density. In this case, $\beta_{a}$ firstly increased when nitrite content was very low $(0.02 \mathrm{~mol} / \mathrm{L})$ and then decreased when nitrite content was high $(0.2 \mathrm{~mol} / \mathrm{L})$, while $\beta_{c}$ and Stern-Geary constant $B$ decreased with the presence of nitrite as shown in Figures 16(c), 16(f), and 16(i).

In $\mathrm{pH} 8.1$ environment only containing $0.1 \mathrm{~mol} / \mathrm{L} \mathrm{SO}_{4}{ }^{2-}$ (Figure 15(i)), the steel was corroded seriously with the absence of nitrite. The presence of $0.02 \mathrm{~mol} / \mathrm{L}$ nitrite led to the increase of cathodic polarization current density and the decrease of anodic polarization current density. Higher nitrite concentration $(0.2 \mathrm{~mol} / \mathrm{L})$ resulted in further decrease of anodic polarization current density and also had an influence on cathodic polarization current density. It can be seen that under the same over potential, the cathodic polarization current in the case of $0.2 \mathrm{~mol} / \mathrm{L}$ nitrite was lower than that in the case of $0 \mathrm{~mol} / \mathrm{L}$ nitrite. After the anodic and cathodic polarization were finished, visual examination of steel surface was performed. Many small pitting holes with the sizes of $0.2 \mathrm{~mm}$ to $1 \mathrm{~mm}$ were observed on the surface of steels immersed in $\mathrm{pH} 8.1$ solutions containing $0.02 \mathrm{~mol} / \mathrm{L}$ nitrite and $0.1 \mathrm{~mol} / \mathrm{L} \mathrm{SO}_{4}{ }^{2-}$, while no rust and no pitting hole were found on the surface of steels immersed in $\mathrm{pH} 8.1$ solutions containing $0.2 \mathrm{~mol} / \mathrm{L}$ nitrite and $0.1 \mathrm{~mol} / \mathrm{L} \mathrm{SO}_{4}{ }^{2-}$. Cathodic Tafel slope $\beta_{c}$ decreased with the presence of nitrite, while anodic Tafel slope $\beta_{a}$ and Stern-Geary constant $B$ firstly increased when nitrite content was very low $(0.02 \mathrm{~mol} / \mathrm{L})$ and then decreased when nitrite content was high $(0.2 \mathrm{~mol} / \mathrm{L})$ as shown in Figures 16(c), 16(f), and 16(i).

When steel is polarized anodically, the steel potential set by potentiostat is greater than self-potential. The electrons produced per unit time by the $\mathrm{Fe} \rightarrow \mathrm{Fe}^{2+}+2 \mathrm{e}^{-}$reaction exceed those consumed per unit time by the $\mathrm{O}_{2}+2 \mathrm{H}_{2} \mathrm{O}+$ $4 \mathrm{e}^{-} \rightarrow 4 \mathrm{OH}^{-}$reaction, and net oxidation occurs at the steel surface. A positive value is consistent with the sign convention that assigns a positive value to the external circuit current. When steel is corroded, the presence of nitrite accelerates the oxidation of $\mathrm{Fe}^{2+}$ into $\mathrm{Fe}_{2} \mathrm{O}_{3}$ or $\gamma \mathrm{FeOOH}$ and causes the formation of a less porous and more compact passive film which inhibits the $\mathrm{Fe} \rightarrow \mathrm{Fe}^{2+}+2 \mathrm{e}^{-}$reaction. The reduction of electrons produced per unit time by the $\mathrm{Fe} \rightarrow \mathrm{Fe}^{2+}+2 \mathrm{e}^{-}$reaction results in the decrease of anodic polarization current. When steel is in passive state, the properties and composition of the passive film are similar to those found in the presence of nitrite [13], so the $\mathrm{Fe} \rightarrow \mathrm{Fe}^{2+}$ $+2 \mathrm{e}^{-}$reaction is little affected and the electrons assigned to the external circuit is not changed. Therefore, there is almost no change in anodic polarization current.

\section{Conclusions}

In this study, the effect of nitrite concentration and $\mathrm{pH}$ on the corrosion of steel has been investigated by means of visual examination, half-cell potential, and anodic and cathodic polarization curves. Based on the above analysis, the following conclusions can be obtained.

With the presence of nitrite, the corrosion of steel can be inhibited effectively. Chloride threshold level and sulfate threshold level are not only increased with the increasing of nitrite concentration but are also affected by $\mathrm{pH}$. Highly alkaline environment plays an important role in assisting nitrite to inhibit corrosion.

Chloride-induced corrosion is more prone to initiate than sulfate-induced corrosion in highly alkaline environment, but in neutral environment, when nitrite concentration is equal to or less than $0.053 \mathrm{~mol} / \mathrm{L}$, sulfate-induced corrosion is more likely to occur than chloride-induced corrosion.

For chloride-induced corrosion, using $\mathrm{NO}_{2}{ }^{-} / \mathrm{Cl}^{-}$mole ratio as the parameter to guarantee the inhibition effect is suitable in highly alkaline environment, but not appropriate in weakly alkaline and neutral environments. For sulfateinduced corrosion, $\mathrm{NO}_{2}{ }^{-} / \mathrm{SO}_{4}{ }^{2-}$ cannot be used as the parameter to guarantee the inhibition effect due to the change of its threshold level with nitrite concentration. 
When the steel is in passive state, the presence of nitrite has little influence on anodic/cathodic polarization curves and Stern-Geary constant B. When the steel is corroded, the addition of nitrite has a significant effect on the anodic polarization curve of steel and the Stern-Geary constant $B$.

\section{References}

[1] K. K. Sideris and A. E. Savva, "Durability of mixtures containing calcium nitrite based corrosion inhibitor," Cement and Concrete Composites, vol. 27, no. 2, pp. 277-287, 2005.

[2] K. Y. Ann and N. R. Buenfeld, "The effect of calcium nitrite on the chloride-induced corrosion of steel in concrete," Magazine of Concrete Research, vol. 59, no. 9, pp. 689-697, 2007.

[3] M. Balonis and F. P. Glasser, "Calcium nitrite corrosion inhibitor in portland cement: influence of nitrite on chloride binding and mineralogy," Journal of the American Ceramic Society, vol. 94, no. 7, pp. 2230-2241, 2011.

[4] C. Alonso and C. Andrade, "Effect of nitrite as a corrosion inhibitor in contaminated and chloride-free carbonated mortars," ACI Materials Journal, vol. 87, no. 2, pp. 130-137, 1990.

[5] V. T. Ngala, C. L. Page, and M. M. Page, "Corrosion inhibitor systems for remedial treatment of reinforced concrete. Part 1: calcium nitrite," Corrosion Science, vol. 44, no. 9, pp. 2073-2087, 2002.

[6] M. B. Valcarce, C. López, and M. Vázquez, "The role of chloride, nitrite and carbonate ions on carbon steel passivity studied in simulating concrete pore solutions," Journal of the Electrochemical Society, vol. 159, no. 5, pp. C244-C251, 2012.

[7] P. Montes, T. W. Bremner, and D. H. Lister, "Influence of calcium nitrite inhibitor and crack width on corrosion of steel in high performance concrete subjected to a simulated marine environment," Cement and Concrete Composites, vol. 26, no. 3, pp. 243-253, 2004.

[8] I. L. Kondratova, P. Montes, and T. W. Bremner, "Natural marine exposure results for reinforced concrete slabs with corrosion inhibitors," Cement and Concrete Composites, vol. 25, no. 4-5, pp. 483-490, 2003.

[9] M. B. Valcarce and M. Vázquez, "Carbon steel passivity examined in alkaline solutions: the effect of chloride and nitrite ions," Electrochimica Acta, vol. 53, no. 15, pp. 5007-5015, 2008.

[10] L. Mammoliti, C. M. Hansson, and B. B. Hope, "Corrosion inhibitors in concrete. Part II: effect on chloride threshold values for corrosion of steel in synthetic pore solutions," Cement and Concrete Research, vol. 29, no. 10, pp. 1583-1589, 1999.

[11] A. Królikowski and J. Kuziak, "Impedance study on calcium nitrite as a penetrating corrosion inhibitor for steel in concrete," Electrochimica Acta, vol. 56, no. 23, pp. 7845-7853, 2011.

[12] P. Garcés, P. Saura, E. Zornoza, and C. Andrade, "Influence of $\mathrm{pH}$ on the nitrite corrosion inhibition of reinforcing steel in simulated concrete pore solution," Corrosion Science, vol. 53, no. 12, pp. 3991-4000, 2011.

[13] M. B. Valcarce and M. Vázquez, "Carbon steel passivity examined in solutions with a low degree of carbonation: the effect of chloride and nitrite ions," Materials Chemistry and Physics, vol. 115, no. 1, pp. 313-321, 2009.

[14] M. Reffass, R. Sabot, M. Jeannin, C. Berziou, and P. Refait, "Effects of $\mathrm{NO}_{2}{ }^{-}$ions on localised corrosion of steel in $\mathrm{NaHCO}_{3}$ $+\mathrm{NaCl}$ electrolytes," Electrochimica Acta, vol. 52, no. 27, pp. 7599-7606, 2007.
[15] P. Garcés, P. Saura, A. Méndez, E. Zornoza, and C. Andrade, "Effect of nitrite in corrosion of reinforcing steel in neutral and acid solutions simulating the electrolytic environments of micropores of concrete in the propagation period," Corrosion Science, vol. 50, no. 2, pp. 498-509, 2008.

[16] S. Matsuda and H. H. Uhlig, "Effect of $\mathrm{pH}$, sulfates, and chlorides on behavior of sodium chromate and nitrite as passivators for steel," Journal of Electrochemical Society, vol. 111, no. 2, pp. 156-161, 1964.

[17] T. Cheng, J. Lee, and W. Tsai, "Corrosion of reinforcements in artificial sea water and concentrated sulfate solution," Cement and Concrete Research, vol. 20, no. 2, pp. 243-252, 1990.

[18] A. J. Al-Tayyib and M. S. Khan, "Effect of sulfate ions on the corrosion of rebars embedded in concrete," Cement and Concrete Composites, vol. 13, no. 2, pp. 123-127, 1991.

[19] O. S. B. Al-Amoudi and M. Maslehuddin, "The effect of chloride and sulfate ions on reinforcement corrosion," Cement and Concrete Research, vol. 23, no. 1, pp. 139-146, 1993.

[20] N. R. Jarrah, O. S. B. Al-Amoudi, M. Maslehuddin, O. A. Ashiru, and A. I. Al-Mana, "Electrochemical behaviour of steel in plain and blended cement concretes in sulphate and/or chloride environments," Construction and Building Materials, vol. 9, no. 2, pp. 97-103, 1995.

[21] H. A. F. Dehwah, M. Maslehuddin, and S. A. Austin, "Longterm effect of sulfate ions and associated cation type on chloride-induced reinforcement corrosion in Portland cement concretes," Cement and Concrete Composites, vol. 24, no. 1, pp. 17-25, 2002.

[22] M. G. Pujar, T. Anita, H. Shaikh, R. K. Dayal, and H. S. Khatak, "Use of electrochemical noise (EN) technique to study the effect of sulfate and chloride ions on passivation and pitting corrosion behavior of 316 stainless steel," Journal of Materials Engineering and Performance, vol. 16, no. 4, pp. 501-506, 2007.

[23] E. E. Abd El Aal, S. Abd El Wanees, A. Diab, and S. M. Abd El Haleem, "Environmental factors affecting the corrosion behavior of reinforcing steel III. Measurement of pitting corrosion currents of steel in $\mathrm{Ca}(\mathrm{OH})_{2}$, solutions under natural corrosion conditions," Corrosion Science, vol. 51, no. 8, pp. 1611-1618, 2009.

[24] M. Stern and A. L. Geary, "Electrochemical polarization. I. A theoretical analysis of the shape of polarization Curves," Journal of the Electrochemical Society, vol. 104, no. 1, pp. 56-63, 1957.

[25] P. Ghods, O. B. Isgor, G. McRae, and T. Miller, "The effect of concrete pore solution composition on the quality of passive oxide films on black steel reinforcement," Cement and Concrete Composites, vol. 31, no. 1, pp. 2-11, 2009.

[26] M. Moreno, W. Morris, M. G. Alvarez, and G. S. Duffó, "Corrosion of reinforcing steel in simulated concrete pore solutions effect of carbonation and chloride content," Corrosion Science, vol. 46, no. 11, pp. 2681-2699, 2004.

[27] B. Huet, V. L'Hostis, F. Miserque, and H. Idrissi, "Electrochemical behavior of mild steel in concrete: influence of $\mathrm{pH}$ and carbonate content of concrete pore solution," Electrochimica Acta, vol. 51, no. 1, pp. 172-180, 2005.

[28] E. E. Stansbury, Fundamentals of Electrochemical Corrosion, pp. 233-254, ASM International, Materials Park, Ohio, USA, 2000.

[29] M. J. Pryor, “The significance of the flade potential," Journal of the Electrochemical Society, vol. 106, no. 7, pp. 557-562, 1959.

[30] H. J. Engell, "Stability and breakdown phenomena of passivating films," Electrochimica Acta, vol. 22, no. 9, pp. 987-993, 1977. 

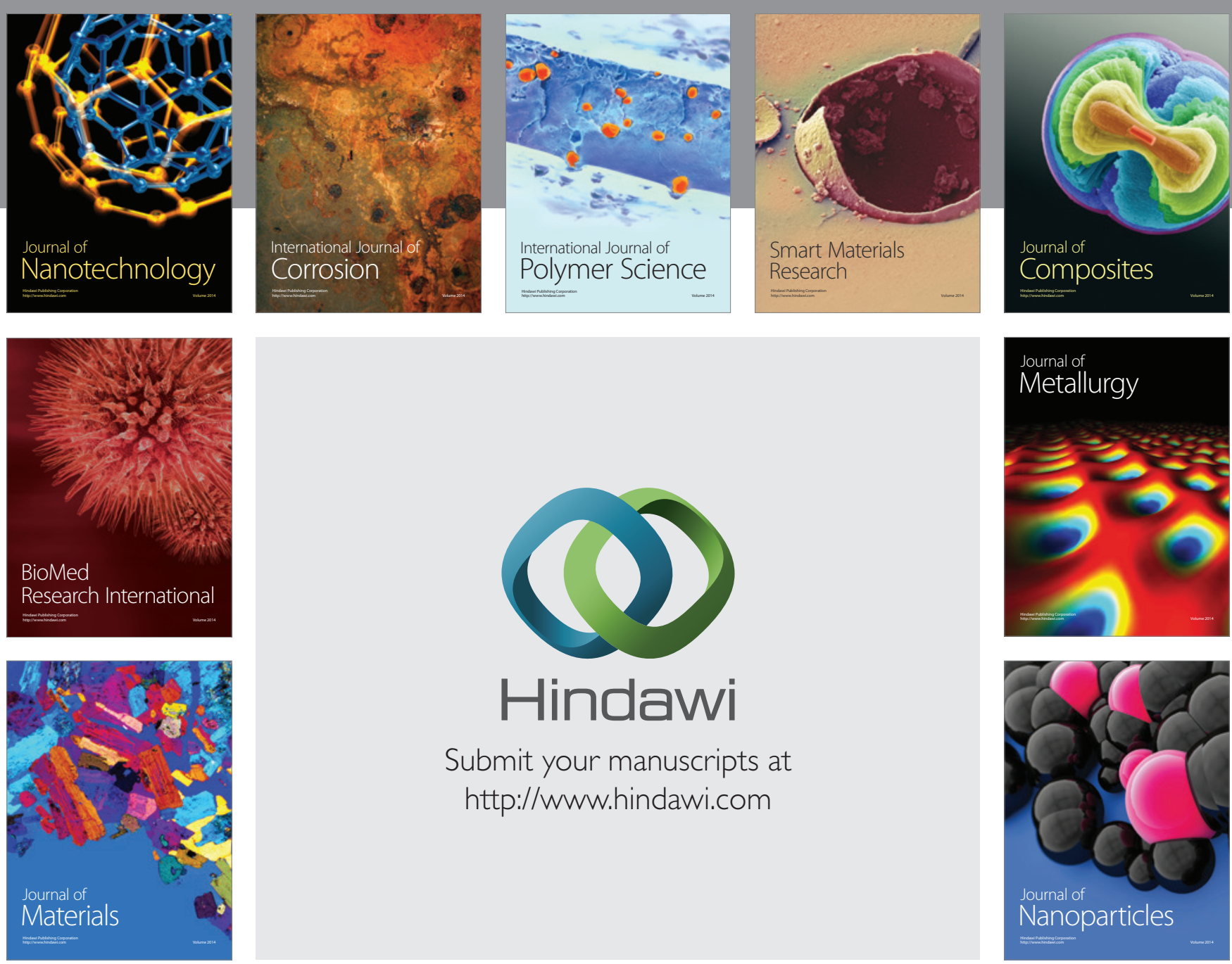

Submit your manuscripts at http://www.hindawi.com
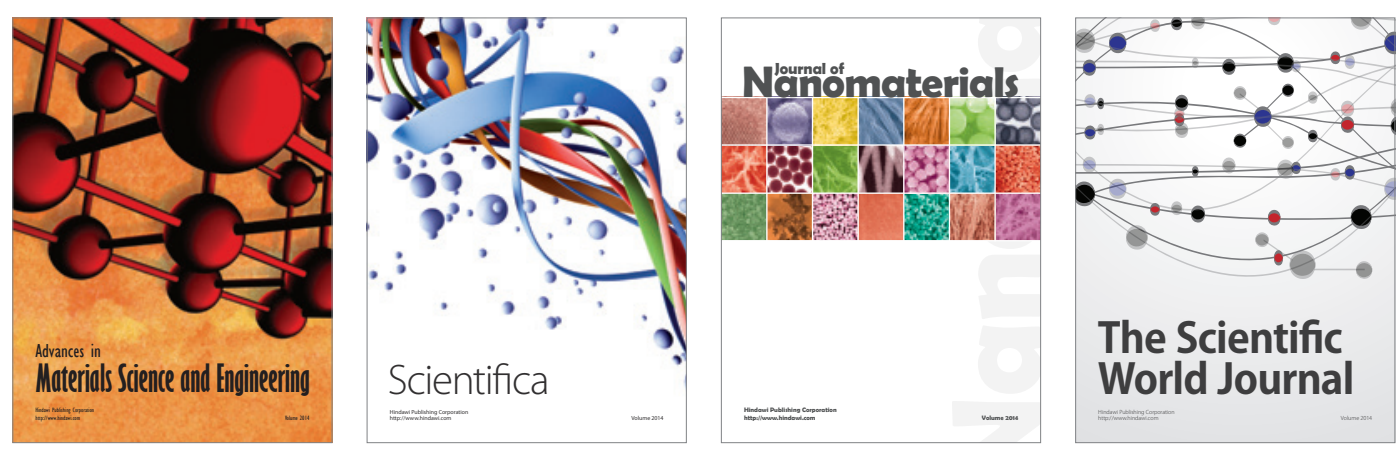

\section{The Scientific World Journal}
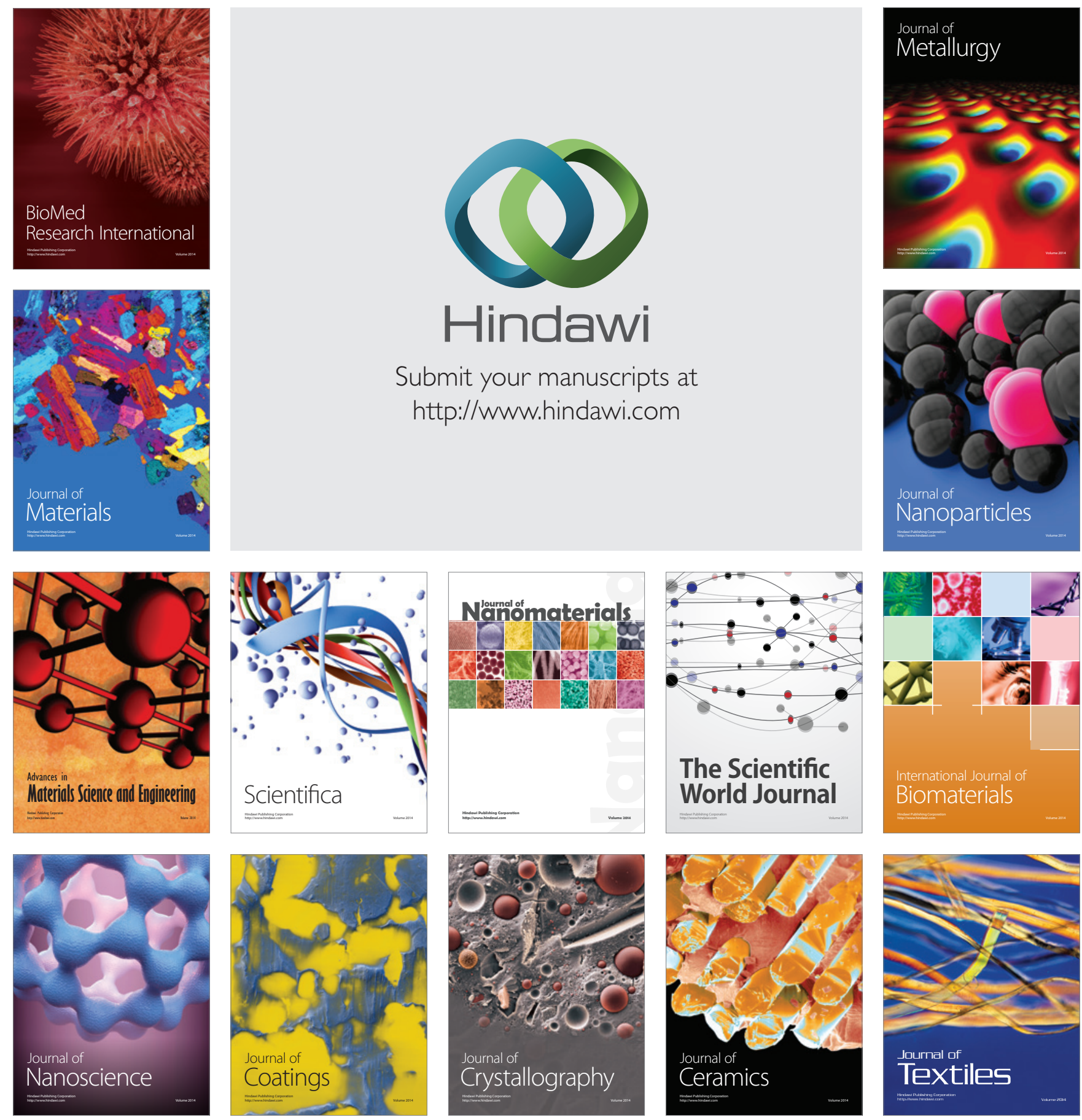